\title{
Irradiation Planning for Fully-Ceramic Micro- Encapsulated Fuel in ATR at LWR-Relevant Conditions: Year-End Report on FY-2011
}

Abderrafi M. Ougouag

R. Sonat Sen

Michael A. Pope

Brian Boer

September 2011

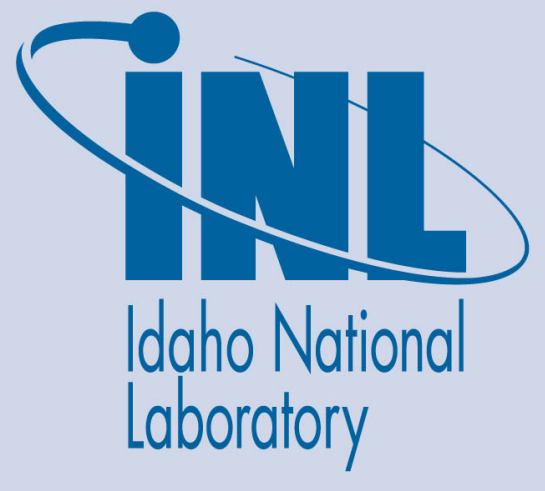

The INL is a U.S. Department of Energy National Laboratory operated by Battelle Energy Alliance 
INL/EXT-11-23450

FCRD-FUEL-2011-000339

\title{
Irradiation Planning for Fully-Ceramic Micro- Encapsulated Fuel in ATR at LWR-Relevant Conditions: Year-End Report on FY-2011
}

\author{
Abderrafi M. Ougouag \\ R. Sonat Sen \\ Michael A. Pope \\ Brian Boer
}

September 2011

\author{
Idaho National Laboratory \\ Fuel Cycle Research \& Development \\ Idaho Falls, Idaho 83415
}

http://www.inl.gov

Prepared for the

U.S. Department of Energy

Office of Nuclear Energy

Under DOE Idaho Operations Office

Contract DE-AC07-05ID14517 


\section{DISCLAIMER}

This information was prepared as an account of work sponsored by an agency of the U.S. Government. Neither the U.S. Government nor any agency thereof, nor any of their employees, makes any warranty, expressed or implied, or assumes any legal liability or responsibility for the accuracy, completeness, or usefulness, of any information, apparatus, product, or process disclosed, or represents that its use would not infringe privately owned rights. References herein to any specific commercial product, process, or service by trade name, trade mark, manufacturer, or otherwise, does not necessarily constitute or imply its endorsement, recommendation, or favoring by the U.S. Government or any agency thereof. The views and opinions of authors expressed herein do not necessarily state or reflect those of the U.S. Government or any agency thereof. 


\section{Co-Authors:}

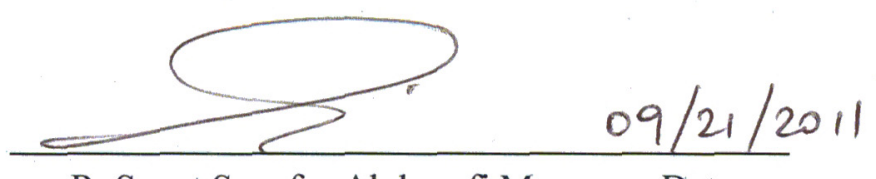

R. Sonat Sen, for Abderrafi M. Date Ougouag, R. Sonat Sen, Michael A.

Pope and Brian Boer

\section{Reviewed by:}

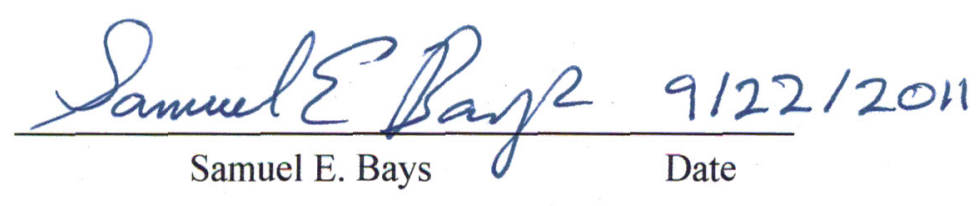

\section{Concurred by:}

Co-Author and Work Package Manager

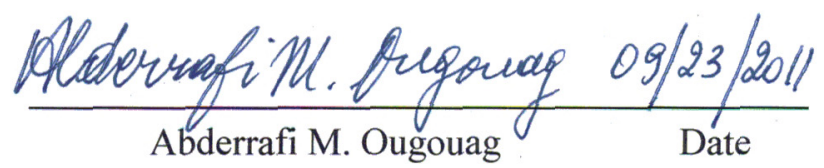


Irradiation planning for Fully-Ceramic Micro-encapsulated fuel in ATR at LWR-relevant conditions

Page Intentionally Left Blank 


\section{ACKNOWLEDGEMENTS}

The authors would like to gratefully acknowledge Dr. Charles A. Wemple of Studsvik-ScandPower for his instrumental help in the computation of dpa values. 
Irradiation planning for Fully-Ceramic Micro-encapsulated fuel in ATR at LWR-relevant conditions 


\section{SUMMARY}

Heretofore, the principal focus of the Deep Burn Project was to plan, carry out, and evaluate the process of once-through burning of plutonium $(\mathrm{Pu})$ and minor actinides (MA), i.e., residual transuranics (TRU) from used fuel in a reactor. First, transmutation or fissioning, collectively termed burning, in a high temperature reactor (HTR) was considered. This included evaluating both the pebble bed and the prismatic block HTR as a platform for deep burning of the plutonium and minor actinides. In the second half of FY-2011, the Idaho National Laboratory, along with the other project participants, started evaluating the possible use of existing, current generation, light water reactors (LWRs) as the platform for deployment of the Deep Burn concept. Therefore, starting in March 2011, the INL has been evaluating the neutronic design and feasibility of the Deep Burn concept in a LWR. This application would use a new type of fuel. The new fuel form, termed "Fully-Ceramic Micro-encapsulated" (FCM) fuel, is a concept that borrows the tri-isotropic (TRISO) fuel particle design from high-temperature reactor technology. In the Deep Burn LWR (DB-LWR) concept, these fuel particles are pressed into compacts using silicon carbide ( $\mathrm{SiC}$ ) for matrix material and are loaded into fuel pins for use in conventional LWRs. The TRU loading comes from the spent fuel of a conventional LWR after 5 years of cooling.

In conjunction with designing the fuel and evaluating its neutronic performance, the INL has also been evaluating the material performance of the fuel using modeling as the means of such an evaluation. These two activities are reported upon in two companion reports [B. Boer, et. al., FCR\&D-2011-000338 or INL/EXT-11-23313, and R. S. Sen et al., FCR\&D-2011- 00037 or INL/EXT-11-23269]. Although the fuel modeling uses a state-of-the-art code for evaluating the failure frequency of the fuel, it is still necessary for the fuel to be tested experimentally. The main reason for this is that the fuel type under consideration is new and has not been previously tested. Furthermore, the code, though verified, was never validated for this new type of fuel as the relevant experimental data were never previously generated. It is important to note, however, that although a formal validation was not carried out, the code predictions matched systematically the available experimental results for $\mathrm{UO}_{2}$-based TRISO fuel from the Next Generation Nuclear Plant (NGNP) project. This should provide confidence that the code predictions are likely to be correct for DB fuel, provided the modifications incorporated into the code capture all the differences in artifacts between the two types of fuel. However, the only sure way to verify that this is indeed a fact is to carry out (at least some) experimental tests on the DB fuel. The modifications to the fuel modeling code are discussed in the companion report [B. Boer, et. al., FCR\&D2011-000338 or INL/EXT-11-23313].

Recently, the INL Deep Burn team and its partners outside the INL have been considering the possible use of FCM fuel in ordinary current generation LWRs using fresh $\mathrm{UO}_{2}$ fuel kernels rather than $\mathrm{Pu}$ and MA. The INL also considered uranium silicide and uranium nitride kernels. All of these fuel designs are new and untested. For the $\mathrm{UO}_{2}$-based fuel, the principal difference between the new fuel and the NGNPtype fuel is in the enrichment and in the use of a $\mathrm{SiC}$ matrix rather than of a graphite one. For the other two cases, in addition to the different matrix, the physical and chemical forms of the fissile materials are different. All of these new fuel designs are untested and modeling will certainly not be sufficient to provide the confidence levels necessary to fuel design licensing. Therefore, as the study of the use of FCM fuel in LWRs progresses and as the design of that fuel matures, the necessity for testing such fuel will arise. The preparations reported on in the present document are in essence the first steps toward that future testing.

As initially charted at the beginning of the fiscal year, the main objective of this report is to present elements of irradiation planning methodology for testing DB-FCM fuel in the LWR context. These elements are:

- The methodology assembled and tested for computing the amount of radiation damage that accumulates in the FCM-DB-LWR fuel as it is depleted to full burnup levels. 
- The determination of the ATR experimental fluence that produces the same accumulated damage in the test samples as would arise in the actual fuel in an operating DB-LWR fueled with DBFCM fuel

- The strategy selected for carrying out, in the future, the design and planning of the physical layout of the experiments in the Advanced Test Reactor (ATR)

- The methodology selected for assessing experimental results, specifically the use of the PASTA code in conjunction with the neutronic models to predict the fuel samples behavior at various levels of irradiation and compare predicted and observed behaviors. The theory activity should provide guidance to the experimental design and in return receive feedback on the modeling code and guidance for improving it. This element of the FY-2011 goal is satisfied primarily by reference to the companion report on material performance of the fuel [B. Boer, et. al., FCR\&D2011-000338 or INL/EXT-11-23313].

This report presents the estimation of required ATR irradiation levels for the DB-FCM fuel design (fueled with $\mathrm{Pu}$ and MAs). The fuel and assembly designs are those considered in the companion report mentioned above [R. S. Sen et al., FCR\&D-2011- 00037 or INL/EXT-11-23269]. These results, pertaining to the DB-FCM fuel, are definitive in as much as the design of said fuel is definitive.

In addition to the work performed, as required, for DB-FCM fuel, work has started in a preliminary fashion on single-cell $\mathrm{UO}_{2}$ and $\mathrm{UN}$ fuels. These latter activities go beyond the original charter of this project and although the corresponding work is incomplete, significant progress has been achieved. However, in this context, all that has been achieved is only preliminary because the corresponding fuel designs are neither finalized nor optimized. In particular, the $\mathrm{UO}_{2}$ case is unlikely to result in a viable fuel design if limited to enrichment at or under 20 weight \% in U-235. The UN fuel allows reasonable length cycles and is likely to make an optimal design possible.

Despite being limited to preliminary designs and offering only preliminary conclusions, the irradiation planning tasks for $\mathrm{UO}_{2}$ and $\mathrm{UN}$ fuels that are summarized in this report are useful to the overall goal of devising and deploying FCM-LWR fuel since the methods acquired and tested in this project and the overall procedure for planning will be available for planning tests for the finalized fuel design. Indeed, once the fuel design is finalized and the expected burnup level is determined, the methodology that has been assembled will allow the prompt finalization of the neutronic planning of the irradiation experiment and would provide guidance on the expected experimental performance of the fuel. Deviations from the expected behavior will then have to be analyzed and the outcome of the analysis may be corrections or modifications for the assessment models as well as, possibly, fuel design modifications, and perhaps even variation of experimental control for future experimental phases.

This report starts with a summary description of the current understanding of the fuel design. Then the elements identified above are addressed in turn.

The principal conclusion reached thus far is that the irradiation of FCM fuel in ATR is possible up to levels that are compatible with the goal of testing DB-FCM-LWR fuel. As a corollary, it should also be possible (and more easily so) to test FCM-LWR fuel that is based on the use of $\mathrm{UO}_{2}$ or UN instead of $\mathrm{Pu}$ and minor actinides.

As stated above, in addition to the above mentioned goals, two companion documents [B. Boer, et. al., FCR\&D-2011-000338 or INL/EXT-11-23313, and R. S. Sen et al., FCR\&D-2011- 00037 or INL/EXT11-23269], respectively, report on the neutronic development of the concept and on the use of the PASTA 
code to evaluate the integrity of FCM fuel for normal operation conditions at various levels of depletion and in a simulated LOCA transient.

Although the subject task of this report is by design a preliminary one, several definitive and intermediate goals have been accomplished that are relevant to the future path. Among these is the computation of a damage function for $\mathrm{SiC}$ that is independent of fuel design. In addition, for the interim fuel design, flux levels and neutron spectra have been derived for 48 depletion levels of two Deep Burn situations relevant to LWR operating conditions. These are, respectively, for a soft spectrum location and for a relatively harder spectrum location in a TRU-fueled FCM Deep Burn LWR fuel assembly. In addition to these two situations, neutron spectra were generated for a $\mathrm{UO}_{2}$-fueled FCM fuel cell and for a UN-fueled FCM fuel cell. The number of depletion steps considered for these two latter cases are fewer than those of the DB cases because these latter two fuels only allow the achievement of shorter cycle lengths.

In the cases of the Deep Burn FCM fuels, the neutron spectra and SiC damage functions were then folded to generate displacements per atom per unit fluence for each depletion time step, thus capturing the effect of spectral shifts that arise during depletion. This last computed quantity was then multiplied by the fluence level of the depletion step to generate the accumulated dpa value for that time step. The process was repeated for all depletion time steps and the obtained values added together to generate a dpa value for the $\mathrm{SiC}$ at end of life for the fuel. The $\mathrm{SiC}$ of the TRISO particle and the $\mathrm{SiC}$ of the matrix material were considered separately, however, the difference of the corresponding spectra was found to be negligible, and hence only one value is reported and recognized as applying to both the within TRISO and within matrix cases.

The prediction of irradiation needs follows the same approach. Given the damage function for SiC and the group-wise flux levels in the various irradiation holes of the Advanced Test Reactor (ATR), a dpa accumulation rate was generated for each irradiation facility. The irradiation time required to simulate $\mathrm{SiC}$ radiation ageing to a specified level of depletion is then obtained simply by forming the ratio of the dpa level (as predicted in this report for that level of depletion) to the dpa accumulation rate in the ATR facility.

Besides the prediction of irradiation times, preliminary work was carried out on other aspects of irradiation planning. In particular, a method for evaluating the interplay of depletion, material performance modeling and irradiation is identified by reference to a companion report. Another area that was addressed in a preliminary fashion is the identification and selection of a strategy for the physical and mechanical design of the irradiation experiments. The principal conclusion is that the similarity between the FCM fuel and the fuel compacts of the Next Generation Nuclear Plant prismatic design are strong enough to warrant using irradiation hardware designs and instrumentation adapted from the AGR irradiation tests. Modifications, if found necessary, will probably be few and small, except as pertains to the water environment and its implications on the use of $\mathrm{SiC}$ cladding or $\mathrm{SiC}$ matrix with no additional cladding. 


\section{CONTENTS}

ACKNOWLEDGEMENTS. . V

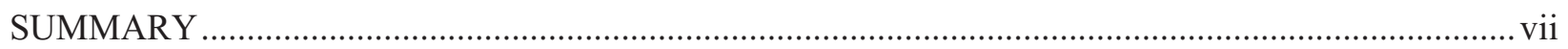

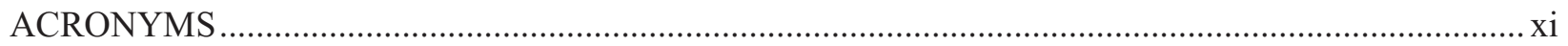

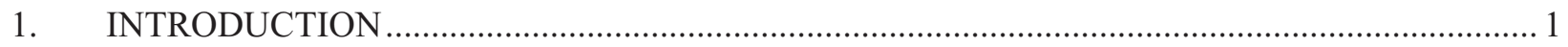

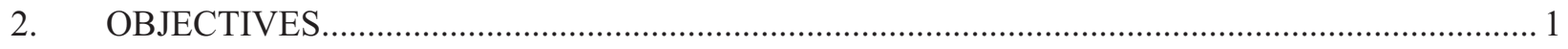

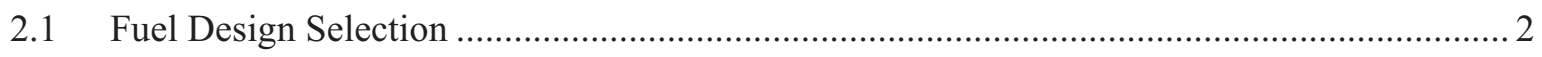

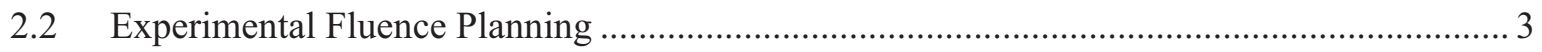

2.3 Fuel Performance Prediction........................................................................................ 3

2.4 Physical Planning of Irradiation.................................................................................. 4

3. CURRENT DESIGN OF THE DEEP BURN FULLY CERAMIC

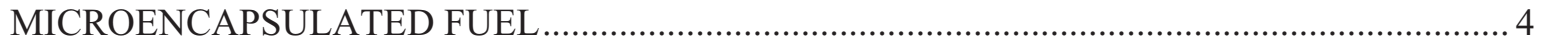

3.1 Deep Burn FCM Fuel design (TRU Only Fuel) ......................................................... 5

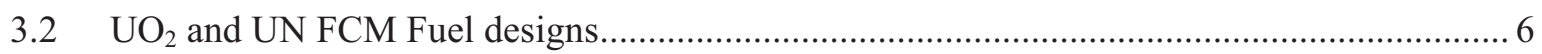

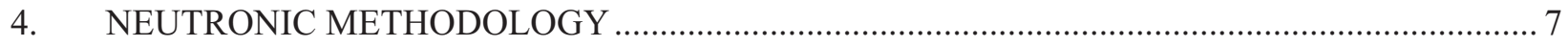

4.1 Computing dpa versus depletion level in FCM-LWR ....................................................... 8

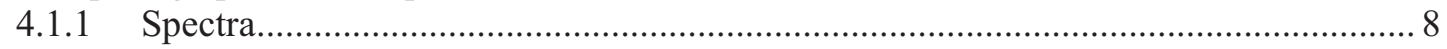

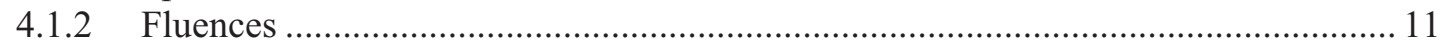

4.1.3 Displacement Kerma Cross Sections and NRT model........................................ 12

4.1.4 Total dpa at each depletion step and at full burnup .............................................. 13

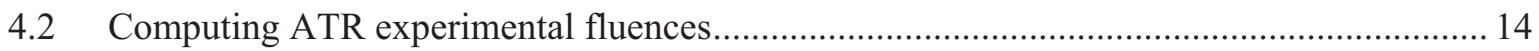

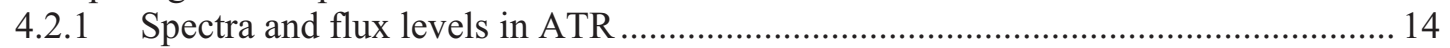

4.2.2 Irradiation times for target fluences in ATR ...................................................... 1

5. Conclusion: Status of Methodology and Planning Development................................................. 1

6. Appendix: Generic Steps in Irradiation Test Planning ..................................................... 1

6.1 Boundary Conditions: the reactor design and its performance limits and objectives ............. 1

6.2 Reactor physics (feasibility, effectiveness, efficiency and safety)...................................... 2

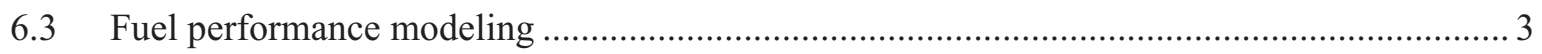

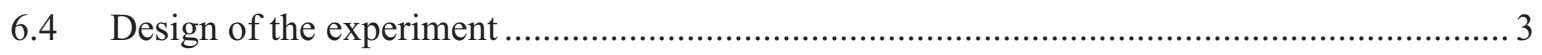

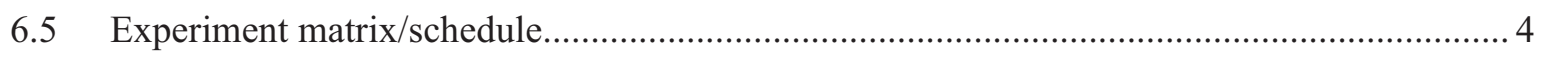

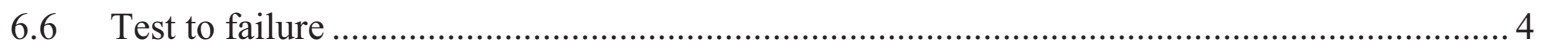

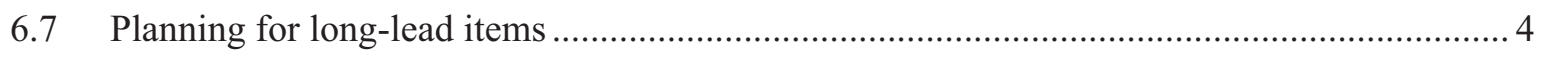

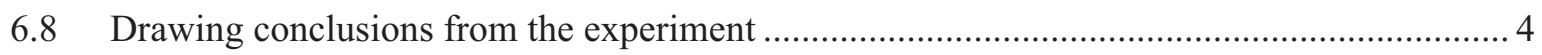

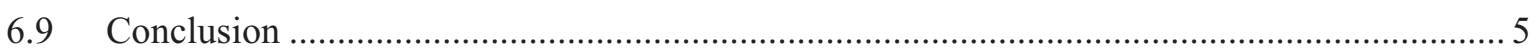

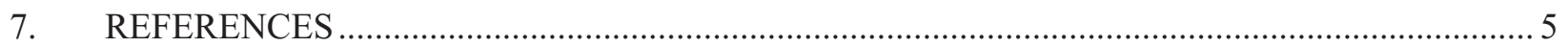




\section{ACRONYMS}

$\begin{array}{ll}\text { DB } & \text { Deep Burn } \\ \text { DB-LWR } & \text { Deep Burn Light Water Reactor } \\ \text { EPR } & \text { European Pressurized water Reactor } \\ \text { FCM } & \text { Fully Ceramic Micro-encapsulated } \\ \text { GWd } & \text { Gigawatt-days } \\ \text { HM } & \text { Heavy Metal } \\ \text { LWR } & \text { Light Water Reactor } \\ \text { MOX } & \text { Mixed Oxide } \\ \text { PF } & \text { Packing Fraction } \\ \text { Pu } & \text { Plutonium } \\ \text { PWR } & \text { Pressurized Water Reactor } \\ \text { TRISO } & \text { Tri-isotropic } \\ \text { TRU }_{\text {TRU-O }} & \text { Transuranic } \\ \text { UO }_{2} & \text { Transuranic Oxide }\end{array}$





\section{IRRADIATION PLANNING FOR FULLY-CERAMIC MICRO-ENCAPSULATED FUEL IN ATR AT LWR- RELEVANT CONDITIONS:}

\section{YEAR-END REPORT ON FY-2011 WORK}

\section{INTRODUCTION}

Over the past few years, the Deep Burn project has evaluated the prospect of using high temperature reactors (HTRs) for reducing legacy inventories of transuranic (TRU) isotopes from used light water reactor (LWR) fuel. ${ }^{1}$ This reduction is to be achieved by transmuting the undesirable isotopes, primarily through fissioning or "burning" them. Both pebble bed ${ }^{2}$ and prismatic designs ${ }^{3}$ were conceptualized and significant design activities and analyses were performed on them. During Fiscal Year 2011, the focus of the Deep Burn Project shifted to a once-through burning of the TRU materials in modified LWRs. The modification of the LWRs pertains primarily to the form of the fuel to be used. The new fuel form under consideration for use in the Deep Burn LWRs (DB-LWR) is Fully-Ceramic Micro-encapsulated (FCM) fuel, a concept that borrows the tri-isotropic (TRISO) fuel particle design from high-temperature reactor technology. ${ }^{4}$ In the DB-LWR concept, these fuel particles would be pressed into compacts using $\mathrm{SiC}$ as the matrix material and would be loaded into fuel pins for use in conventional or latter-generation LWRs. The TRU loading is assumed to come from the used fuel of a conventional LWR cooled for 5 years following discharge.

The HTR fuel based on $\mathrm{UO}_{2}$ in TRISO particle within a graphite matrix has been thoroughly investigated in the Next Generation Nuclear Plant (NGNP) project. Those investigations included experimental tests [5,6], some of which have been completed and some of which are still ongoing. In contrast, the FCM fuel based on plutonium $(\mathrm{Pu})$ and minor actinides (MAs) with the TRISO particles embedded in a SiC matrix has never been tested. Although many features of these two types of fuel may be similar, the differences are significant enough to warrant a separate irradiation testing program. This is even more strongly necessary in the case of the UN-based FCM fuel now considered for use in LWRs. Even the most advanced modeling tools available, such as the PASTA code [7], could not bridge the gap between the known on HTR fuels and the unknowns on FCM fuels. For example, many of the correlations for volatile species generation used for HTR fuels would not be valid for DB fuel or for UN, yet these are essential to the estimation of fuel durability or fuel failures under irradiation. Although the PASTA code has been modified for the purpose of analyzing DB-FCM fuel, uncertainties remain [B. Boer, et. al., FCR\&D-2011-000338 or INL/EXT-1123313], and a supporting experimental program cannot be dispensed with.

The cases to be considered could vary since a completely finalized design for a DB-LWR reactor is not frozen yet. However, a reasonably optimized design has been reached [see R. S. Sen et al., FCR\&D-201100037 or INL/EXT-11-23269] and the corresponding fuel is considered in this study. The preliminary cases for UO2 and UN fuels are just that: preliminary since the design of a FCM-based LWR has also not been devised.

Finally, to conclude this introduction, it is noted that general considerations on how irradiation experiments must be planned are presented in an Appendix included as Section 6. The present report presents progress in planning of an irradiation experiment for DB-FCM-LWR and U-FCM-LWR fuels based on the approach summarized in that Section.

\section{OBJECTIVES}

The objective of this task within the Deep Burn project is to initiate the planning for irradiation testing of FCM fuel suitable for application in LWRs used in the Deep Burn mode of operation. However, work on 
the Deep Burn LWR concept at the Idaho National Laboratory started, as scheduled, only in the second quarter of the fiscal year. Consequently, a fully optimized, finalized, design of the FCM for LWR application has not been produced. Therefore this irradiation design planning study will use as basis the current state of the fuel design, with the understanding that future revisions will incorporate the then-current preferred fuel design.

The specific objectives for FY-2011 are limited to acquiring and testing the relevant irradiation planning neutronic methodology. The other aspects of planning irradiation testing are also discussed in this report, but only from a strategy selection perspective. In particular, the similarities of the new FCM fuel with the compacts of the prismatic HTR fuel is taken advantage of to show a path for the leveraging of the physical design of the AGR fuel tests.

The design of a fuel testing irradiation experiment must necessarily comprise the following components:

- Selection of the fuel design(s) to be tested

- Neutronic design of the experiment (dose/fluence prescription)

- Performance prediction (failure prediction)

- Physical planning and design of experiment

These are discussed in turn, next.

\subsection{Fuel Design Selection}

The fuel intended for use in the context of the Deep Burn application in a LWR consists of TRISO particles embedded in a silicon carbide ( $\mathrm{SiC}$ ) matrix. The mix (matrix-particles) is to be shaped into fuel-pellet-sized cylindrical compacts. The compacts are then assembled into fuel rods held together by a cladding material that could also be made of Zircalloy or SiC, although it could also be made of some other material. At present, Zircalloy-4 is the cladding material considered for DB-FCM fuel while SiC is the most likely candidate for cladding material for the future FCM-LWR fuel. The design of the TRISO particles has been based entirely on the TRISO particles of the NGNP project and for the Deep Burn application this design is considered either final or nearly so. The original charter of the present project was the design of an irradiation experiment for the fuel just described. However, recently, the scope of use of TRISO-based fuels in LWRs has shifted to that of using fresh $\mathrm{UO}_{2}$ or some other fuel rather that $\mathrm{Pu}$ and minor actinides, thus departing from the original Deep Burn mission. Therefore, a new fuel has to be investigated and a related experiment designed. Two Deep Burn application fuel cases, as initially chartered, are presented in this report. In addition, preliminary steps on a $\mathrm{UO}_{2}$ case and a Uranium Nitride (UN) case are briefly summarized. However, it must be emphasized that the $\mathrm{UO}_{2}$ an $\mathrm{UN}$ cases are necessarily preliminary in nature, since the $\mathrm{UO}_{2}$-based and UN-based FCM fuel designs for use in LWRs have not been finalized. In particular, neither the $\mathrm{UN}$ nor the $\mathrm{UO}_{2}$ fuels in this study was optimized. The designs merely assume that the kernel is $\mathrm{UN}$ or $\mathrm{UO}_{2}$ in replacement of the mix in the Deep Burn TRISO particles, although the kernel size may be changed from the NGNP design case. The $\mathrm{UO}_{2}$ fuel does not achieve reasonable cycle lengths when used in a LWR and all indications are that it cannot be optimized further, thus limiting the scope of the irradiation planning study that was carried out.

In the context of TRISO-based fuel, a design may vary in many aspects. These aspects include the fuel kernel diameter, its isotopic composition (including the level of enrichment), the nature and thickness of the various coating layers, and the presence (or absence) of getters to immobilize volatile species that form by mutation or from fission events as well as from chemical effect within the fuel kernel and the coating layers internal to the $\mathrm{SiC}$ layer. Given these numerous degrees of freedom, it is no surprise that early in the consideration of FCM fuel for LWR applications a final optimized fuel design had not been reached. However, since the end of the modeling phase of the study presented here, a companion effort has produced 
a reasonable interim fuel design for used in LWRs in the sense that it was designed to achieve fuel cycle lengths similar to those of ordinary LWR fuels. Unfortunately that design became available too late for full consideration in this irradiation planning study. The new design will be considered in follow-on work (although the corresponding spectra are summarized). The actual designs used in this study are presented in quantitative details in the section on neutronic design and damage calculation.

\subsection{Experimental Fluence Planning}

An irradiation experiment on a given material must achieve fluences that are equivalent (in a sense to be clarified in detail in Section 4) to the fluences expected to be experienced by the material in the course of its normal use in a reactor. For this purpose fluence planning must be an integral part of the overall irradiation planning. The main principle used in this study is based on considering that behavior of irradiated materials is governed primarily by the number of atomic displacements that have taken place therein. In other words, radiation damage is characterized by the number of atomic displacements and radiation effect on properties is assumed to correlate well with the level of damage thus characterized. Therefore, in this work, it is assumed that two fluence levels received by a material (in different spectra and/or in different reactors) are equivalent if they produce the same number of atomic displacements in the material. The fluence planning part of irradiation experiment planning consists in determining the length of irradiation in a known facility that will produce the same level of atomic displacements in the material under consideration as would irradiation of the material in actual reactor applications up to specified burnup levels.

Experimental fluence planning is discussed in detail in Section 4.

\subsection{Fuel Performance Prediction}

The need to determine fluence levels a fuel sample must receive and to plan the irradiation is driven by the need to determine the material performance of the fuel. That is, the aim of the irradiation experiment is to determine at what fluence level fuel would fail or to demonstrate that it would not fail for all fluence levels expected from operating the reactor up to full burnup. In planning the experiment, it is important to use guidance from model that predict fuel failure (or the absence thereof) as a function of accumulated fluence. Such use of a fuel performance code may guide in the prediction of the fluence levels at which failures may start to be observed and hence help in planning the experimental fluence level(s). In return, the experimental results would be helpful in calibrating, adjusting, and validating the predictive code. During the brief performance period a fuel performance prediction code was used in a companion task, but the implications of that work have not yet been incorporated into the irradiation planning work. This should be carried out in the next Fiscal Year. The work just mentioned is reported on in a companion report relating another Deep Burn Project milestone [B. Boer et al FCR\&D-2011-000338 or INL/EXT-11-23313]. That report presents the results of an evaluation of FCM fuel integrity with depletion levels similar to those investigated in the present report. That other report uses the PASTA code to assess the fuel performance under steady state conditions (including depletion) as well as under the conditions induced by a simulated LOCA transient.

Fuel performance prediction is not discussed further in this report. The companion report [B. Boer, et. al., FCR\&D-2011-000338 or INL/EXT-11-23313] may be consulted for details and for an understanding of the correlation between level of depletion and failure rates. Since the level of depletion correlates with the number of displacements per atom (dpa), as shown in Section 4, while depletion also correlates directly (an in the context of the PASTA model) univocally with performance (i.e., failure rates). The correlation between dpa follows directly from these considerations. A quantification of expected failure rates as a function of dpa level (i.e., of dose or of radiation exposure) should be an integral part of final irradiation 
experiment planning. The way this can be devised is by running the PASTA code for specified depletion levels and computing the dpa level for those same depletion levels, then tabulating (and plotting) the failure rates versus dpa levels. The approach may be used to determine the dpa level below which no failures are expected to occur and the level for which the failure rates exceed some prescribed level (e.g., of acceptability). Such a curve would then serve as a guide throughout the experimental phase in correlation with monitoring data.

\subsection{Physical Planning of Irradiation}

Once the target fluences are identified, the means to achieve them must be devised. Irradiation of any sample requires manufacturing the sample and manufacturing a container for that sample that is compatible with the irradiation facility. The strategy proposed for irradiation of FCM fuel in the ATR is based on the recognition that the FCM fuel is likely to be similar to the NGNP fuel in many respects. They both use TRISO particles and they both have those TRISO particles embedded in a matrix. Furthermore, the pellets of the LWR FCM and the fuel compacts of the NGNP are similar in size and shape. It follows that the experimental capsules and associated hardware (including instrumentation and failure detection hardware) of the NGNP experiments (known as the AGR Tests) could be easily adapted to the purposes of the FCM Fuel tests. This strategy is proposed as a way to save on costs and to speedup development process.

The second aspect of means acquisition pertains to access to the facility and scheduling the irradiations. The lead time for access to ATR facilities, especially for long duration irradiation experiments, as the FCM Fuel irradiations are likely to be, is usually long. Consequently access negotiations, or at least access planning, must be initiated as soon as possible.

The physical planning of the irradiation is not addressed further in this report. However, it must be addressed in detail in future revisions, as the target fuel design is finalized. In the interim, reports such as $[5,6]$ may be consulted for details on the rigs, instrumentation and physical design of capsules intended for testing a fuel that is very similar to the FCM. When the physical design is addressed, several factors that differentiate the LWR case from the HTR one will have to be accounted for. Some of these factors, other than radiation, that cause or promote ageing include the presence of water (liquid or vapor) and the history of such presence and the temperature field and temperature history. In addition, the means for controlling the environment (temperature probes/pressure probes/moisture probes) will have to be adapted to the new situation beyond those in use for the AGR experiments. Finally, the monitoring of sample performance and detection of failures will also have to be modified in order to adapt to the $\mathrm{SiC}$ matrix and the possible intentional presence of water in some samples.

\section{CURRENT DESIGN OF THE DEEP BURN FULLY CERAMIC MICROENCAPSULATED FUEL}

Three types of fuel have been considered in this study. The first type is the one initially assigned to this task at the beginning of the Fiscal Year. Namely, irradiation testing was to be planned for FCM fuel containing only Pu and MAs from used LWR fuel. This type of fuel is described in Subsection 3.1. Later on the INL team decided to investigate UO2 and UN fuels in the FCM design. These two fuels are presented in subsequent subsections. 


\subsection{Deep Burn FCM Fuel design (TRU Only Fuel)}

In the course of the neutronic design of a DB-FCM-fueled reactor, the choice of fuel pin and assembly designs was guided by consideration of compatibility with the use of MOX fuel. Therefore, the specifications chosen for initial analysis approximate the lattice of the AREVA EPR ${ }^{\mathrm{TM}}$ in part because this reactor is expected to be available in configurations that can accept a core of $100 \%$ MOX. Initial calculations were performed by assuming that the ordinary $\mathrm{UO}_{2}$ fuel pellets are replaced with the FCM fuel compacts. FCM fuel is constituted of TRISO fuel particles containing TRU- $\mathrm{O}_{\mathrm{x}}$ kernels embedded within a SiC matrix. Table 3-1 shows the dimensions and densities (i.e., specific masses) of the layers of the TRISO particles specified for these initial calculations. The simplifying assumption was made that the kernel diameter can be varied without changing the layer thicknesses, notwithstanding the material integrity implications. Preliminary fuel performance calculations have also been performed to predict the material integrity of the TRISO particles constituents of the FCM fuel. Those calculations, using the PASTA code, ${ }^{7}$ are the subject of a companion report [B. Boer et al FCR\&D-2011-000338 or INL/EXT-11-23313].

Table 3-1. TRISO fuel particle dimensions and physical properties in FCM fuel.

\begin{tabular}{|l|c|c|}
\hline Layer & $\begin{array}{c}\text { Thickness } \\
(\boldsymbol{\mu m})\end{array}$ & $\begin{array}{c}\text { Density } \\
\left(\mathbf{g} / \mathbf{c m}^{\mathbf{3}}\right)\end{array}$ \\
\hline Kernel $\left(\mathrm{TRU}-\mathrm{O}_{\mathrm{x}}+\mathrm{SiC}\right)$ & $350-600^{\mathrm{a}}$ & $10.0^{\mathrm{b}}$ \\
\hline Porous Carbon Buffer & 100 & 1.05 \\
\hline Inner Pyrolytic Carbon & 35 & 1.9 \\
\hline $\mathrm{SiC}$ & 35 & 3.18 \\
\hline Outer Pyrolytic Carbon & 40 & 1.9 \\
\hline
\end{tabular}

The TRU-O ${ }_{x}$ fuel contains primarily neptunium and plutonium with trace amounts of uranium, the vector of which is derived from once-burned LWR fuel. The plutonium oxide is sub-stoichiometric while neptunium and uranium are not. The TRU-O $\mathrm{O}_{\mathrm{x}}$ fuel stoichiometry and composition are:

$$
\left.0.2 \text { w/o (nat. } \mathrm{UO}_{2}\right)+99.8 \mathrm{w} / \mathrm{o}\left(\mathrm{NpO}_{2}+\mathrm{PuO}_{1.8}\right)+\mathrm{SiC} \text { kernel getter. }
$$

$\mathrm{SiC}$ is mixed into the kernel as an oxygen getter. For the purpose of this document, the $\mathrm{SiC}$ volume fraction is given and then the remaining kernel space available is filled with TRU-O $\mathrm{X}_{\mathrm{x}}$ having density of $10.0 \mathrm{~g} / \mathrm{cm}^{3}$. Therefore, the actual kernel density is lower than the value shown in Table 3-1. Nominally, the SiC kernel getter is assumed to take up $25 \%$ of the kernel by volume. This composition is adopted from previous studies of Deep Burn High Temperature Reactors. ${ }^{8}$ Table 3-2 gives the weight percents of heavy metal nuclides in the FCM fuel.

Table 3-2. Heavy metal nuclide weight percents in TRU-Ox fuel.

\begin{tabular}{|l|c|}
\hline Nuclide & Weight Percent \\
\hline U-235 & 0.0014 \\
\hline U-238 & 0.20 \\
\hline Np-237 & 4.94 \\
\hline Pu-238 & 3.00 \\
\hline
\end{tabular}

a. This is the kernel diameter in $\mu \mathrm{m}$. This parameter is varied in the analysis within the bounds shown.

b. Density of kernel shown is TRU-O $\mathrm{O}_{\mathrm{x}}$ component only. Dilution with $\mathrm{SiC}\left(\rho=3.18 \mathrm{~g} / \mathrm{cm}^{3}\right)$ reduces total kernel density. 


\begin{tabular}{|c|c|}
\hline Pu-239 & 58.11 \\
\hline Pu-240 & 21.97 \\
\hline Pu-241 & 5.18 \\
\hline Pu-242 & 6.60 \\
\hline
\end{tabular}

Table 3-3 gives parameters for the reactor design assumed in this stage of the study. As mentioned above, the basic parameters are taken from the AREVA EPR ${ }^{\mathrm{TM}}$ design. ${ }^{9}$ The assumed power rating is $4500 \mathrm{MW}_{\text {th }}$ and the number of $17 \times 17$ fuel assemblies is 241. In order to model the FCM fuel at this initial stage of analysis, the oxide fuel ordinarily used in an EPR is simply replaced with fuel compacts of the type described above having and TRISO particle packing fractions of $\leq 48 \%$, which has been estimated to be the maximum feasible without causing excessive failures. ${ }^{10}$ The cladding is Zircalloy-4 with a mass density of $6.56 \mathrm{~g} / \mathrm{cm}^{3}$. For the single pin cell calculations, an effective pin pitch of $1.32 \mathrm{~cm}$ is used in order to account for the extra water in the empty guide tubes and in the small inter-assembly gap. These same dimensions are used in the assembly calculations presented in Section 4 as well.

Table 3-3. Characteristics of LWR assembly and core initially analyzed.

\begin{tabular}{|l|c|}
\hline \multicolumn{1}{|c|}{ Parameter } & Value \\
\hline Reactor thermal power $\left(\mathrm{MW}_{\mathrm{th}}\right)$ & 4500 \\
\hline Number of Fuel Assemblies & 241 \\
\hline Active Fuel Height $(\mathrm{m})$ & 4.20 \\
\hline Assembly Pitch $(\mathrm{cm})$ & 21.504 \\
\hline Actual Pin Pitch $(\mathrm{cm})$ & 1.27 \\
\hline Effective pin pitch for single cell calculations $(\mathrm{cm})$ & 1.32 \\
\hline Number of fueled pins per $17 \times 17$ assembly & 265 \\
\hline Number of guide tubes per $17 \times 17$ assembly & 24 \\
\hline Fuel Pellet Diameter $(\mathrm{mm})$ & 8.20 \\
\hline Fuel Pin Inner Diameter $(\mathrm{mm})$ & 8.36 \\
\hline Fuel Pin Outer Diameter $(\mathrm{mm})$ & 9.50 \\
\hline Guide Tube Inner Diameter $(\mathrm{mm})$ & 11.4 \\
\hline Guide Tube Outer Diameter $(\mathrm{mm})$ & 12.3 \\
\hline Average Linear Power $(\mathrm{kW} / \mathrm{m})$ & 16.7 \\
\hline Average Power per Volume of Core $\left(\mathrm{MW}_{\mathrm{th}} / \mathrm{m}^{3}\right)$ & 96.2 \\
\hline Average Power per Volume of Fuel Pellet $\left(\mathrm{W} / \mathrm{cm}^{3}\right)$ & 318 \\
\hline
\end{tabular}

\section{$3.2 \mathrm{UO}_{2}$ and UN FCM Fuel designs}

The $\mathrm{UO}_{2}$ and $\mathrm{UN}$ fuel cases are not treated at the full assembly level. Instead single representative cells are devised. The characteristics of these fuel cells are given in Table 3-4. As can be seen, the TRISO particles in these fuel designs are of a larger diameter than the standard TRISO particles of HTR fuel. In addition the nature of the kernel of one of these (UN) is different from that of HTR fuel. Consequently, the results of the irradiation experiments that were conducted for qualifying HTR TRISO fuel particles may not be valid for these new fuels. Another source of difference in behavior is the use of $\mathrm{SiC}$ matrix rather than graphite. The respective shrinking and swelling performances of graphite and $\mathrm{SiC}$ when subjected to neutron 
radiation are dissimilar, and hence their respective impact on the embedded TRISO particles would also be expected to be different.

The unit cells described in the table were used in neutronic computations to determine neutron spectra and to evaluate cycle durations and burned-up fuel properties. The full information on that work are in preparation for publication as an Oak Ridge National Laboratory (ORNL) report with the corresponding input from INL. The INL contribution will be the subject of a separate external publication. ${ }^{11}$

Table 3-4. Characteristics of $\mathrm{UO}_{2}$ and $\mathrm{UN}$ fuel single cell design.

\begin{tabular}{|l|c|c|}
\hline & $\mathrm{UN}$ & $\mathrm{UO}_{2}$ \\
\hline Fuel Type & TRISO & TRISO \\
\hline Fuel Enrichment & $19.90 \%$ & $19.90 \%$ \\
\hline Kernel diameter (micron) & 800 & 800 \\
\hline Buffer thickness (micron) & 100 & 100 \\
\hline Inner PyC thickness (micron) & 35 & 35 \\
\hline SiC layer thickness (micron) & 35 & 35 \\
\hline Outer PyC thickness (micron) & 40 & 40 \\
\hline Packing fraction & $44 \%$ & $44 \%$ \\
\hline Fuel pellet diameter (mm) & 8.2 & 8.2 \\
\hline Fuel pin inner diameter (mm) & 8.36 & 8.36 \\
\hline Fuel pin outer diameter (mm) & 9.5 & 9.5 \\
\hline Fuel cycle length(days) & 1050 & 700 \\
\hline Burnup (MWd/tHM) & $1.99 \mathrm{E}+05$ & $1.96 \mathrm{E}+05$ \\
\hline HM loading/pellet $(\mathrm{g} / \mathrm{cm} 3)$ & 1.9 & 1.14 \\
\hline Cladding material & $\mathrm{SiC}$ & $\mathrm{SiC}$ \\
\hline
\end{tabular}

\section{NEUTRONIC METHODOLOGY}

The neutronic methodology for determination of experimental irradiation fluences consists of three sets of calculations. In the first set, the conditions in the target application are identified and quantified. In the case of use of FCM fuel in LWRs, this means that the neutron spectrum ion the reactor must be characterized and the fluence level that will be experienced by the material to be tested is to be determined. In the case of TRISO particles embedded in $\mathrm{SiC}$ matrix, the fluence received by the $\mathrm{SiC}$ layer in the TRISO and by the $\mathrm{SiC}$ matrix must be quantified. The second set of calculations is to determine the number of displacements per atom (dpa) that result in the $\mathrm{SiC}$ material at these fluences in the prevailing neutron spectrum. The third set of computations pertains to estimating the irradiation time in ATR required to imparting on the experimental sample a fluence equivalent to that received in the actual reactor. Equivalent here means that the two fluences cause the same level of dpa as a measure of damage. This set of computations requires folding the damage function of $\mathrm{SiC}$ with the experimental facility spectra and flux levels. The resulting dpa rate is used to compare with the total dpa level predicted for the reactor and hence computing the required irradiation time. These steps are carried out in this section and the results are shown.

For the cell and assembly calculations, the code DRAGON-4 is used. This is an open-source lattice transport code developed and maintained by École Polytechnique de Montréal [12]. This code contains multiple solution methods and allows for flexible calculation routes and data manipulation. The code also allows for treatment of the double-heterogeneity of the TRISO particles in the fuel directly using the method developed by Hébert [13]. Collision probability calculations were performed using a cross section library generated from ENDF/B-VII and cast in the SHEM-281 energy group structure [14]. 
In LWR analysis, calculations on a single unit cell can be informative with regard to the performance of a certain fuel in the whole core. As a first step, the TRU-only FCM fuel was analyzed as a single unit cell as though it was the only fuel type present in the core. The results are interpreted with the knowledge that if the TRU-only pin were used in conjunction with $\mathrm{UO}_{2}$ pins or assemblies, the overall behavior would be expected to be the composite result of the effects of the TRU-only FCM unit cells and the $\mathrm{UO}_{2}$ unit cells. This was verified in subsequent calculations on full heterogeneous assemblies.

Each type of fuel investigated is depleted based on a flux calculation using a $\mathrm{B}_{0}$ buckling search. At each depletion step, several perturbations on the unit cell are performed for calculation of the various reactivity coefficients.

\subsection{Computing dpa versus depletion level in FCM-LWR}

The process for computation of dpa levels accumulated by the end of each depletion step was described above. Each of those steps is detailed below. The full details on the cell level or assembly level recator physics calculations are available in the companion report on neutronic performance of FCM fuel [see companion report R. S. Sen et al., FCR\&D-2011- 00037 or INL/EXT-11-23269].

\subsubsection{Spectra}

For the cases of fuel containing Pu and MAs, unit cell and assembly calculations have been performed using the DRAGON-4 code to assess the physics attributes of TRU-only FCM fuel pins in an LWR lattice. Depletion calculations assuming an infinite lattice condition were performed with calculations of various reactivity coefficients performed at each step. Unit cells and assemblies containing typical $\mathrm{UO}_{2}$ and mixed oxide (MOX) fuel were analyzed in the same way to provide a baseline against which to compare the TRUonly FCM fuel. Then, assembly calculations were performed evaluating the performance of heterogeneous arrangements of TRU-only FCM fuel pins along with $\mathrm{UO}_{2}$ pins. For the sake of providing limiting values for the damage production, two fuel pins were considered. One pin is located in a zone near other fuel pins and hence is expected to experience a relatively harder spectrum. A second pin was chosen near water filled guide tubes, and hence experiences a relatively softer spectrum. These two chosen pins respective locations are shown in Figure 1 and Figure 2. The figure represent assemblies with black circles for FCM fuel, gray circles for regular $\mathrm{LWR} \mathrm{UO}_{2}$ fuel pins and white circle for water holes. 


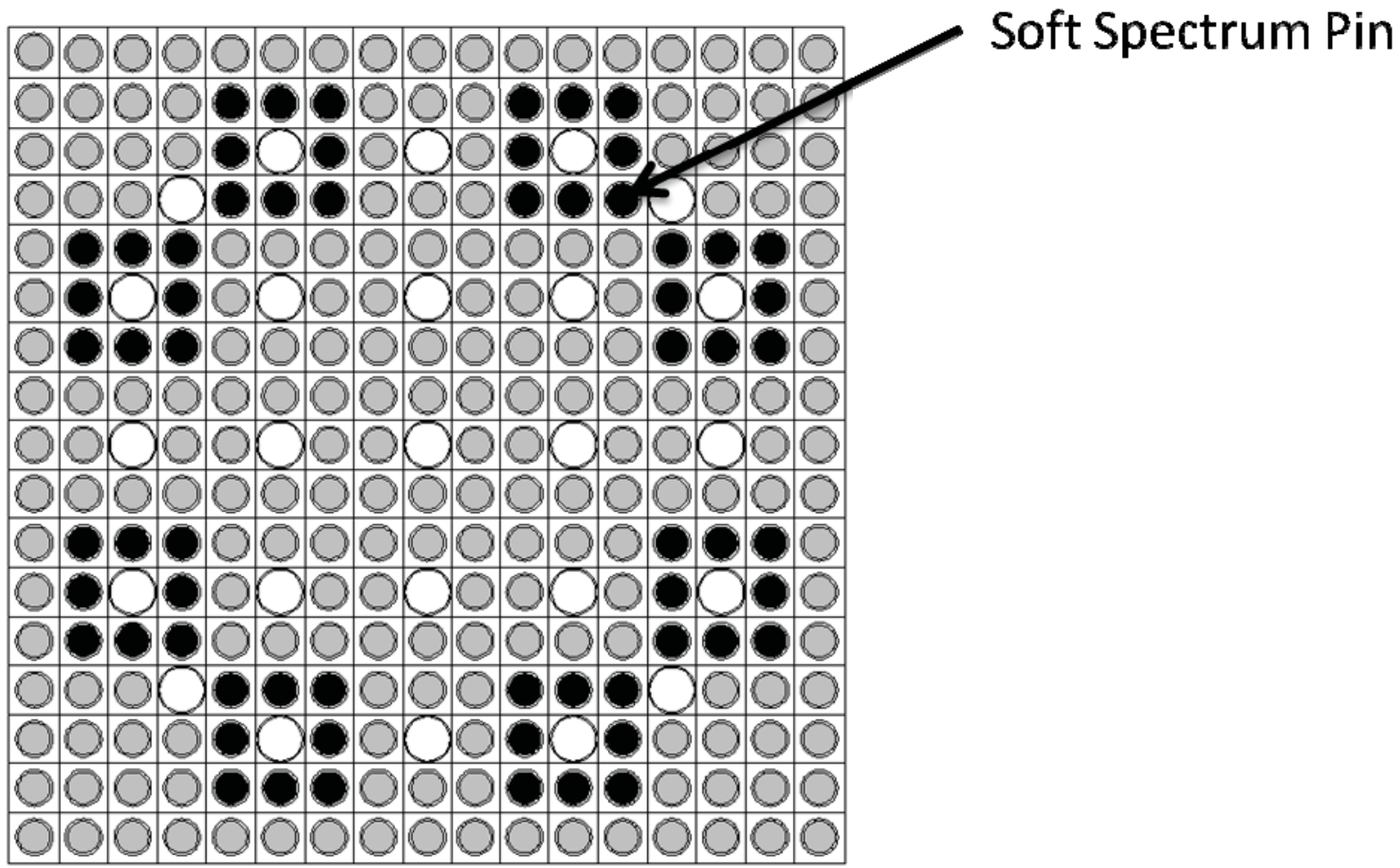

Figure 1: Location of relatively softer spectrum pin

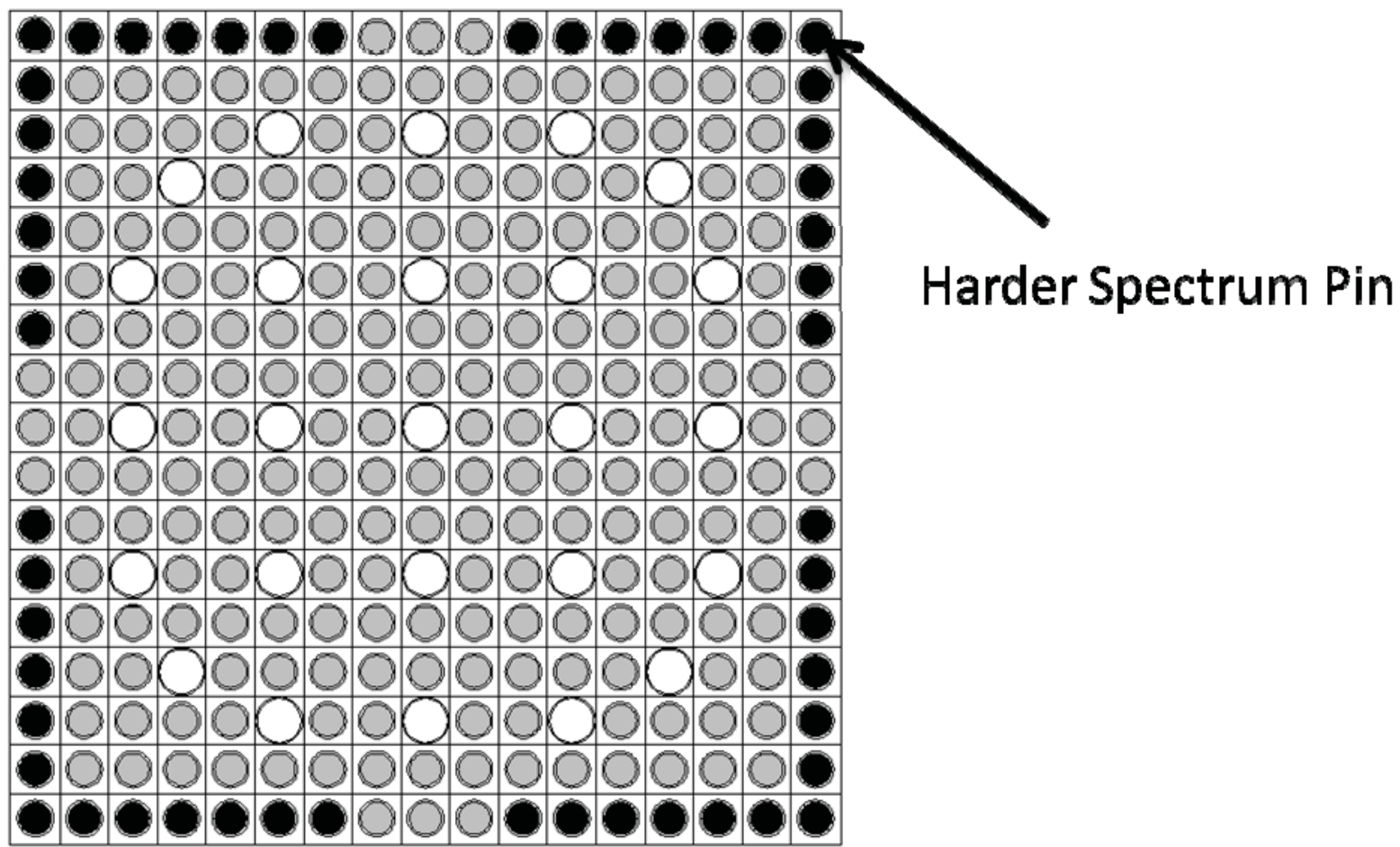

Figure 2:Location of relatively harder spectrum pin 
For each one of these pins a 281-energy-groups spectrum was generated. The two spectra are shown in Figure 3 and Figure 4. The spectra were computed for each depletion step. In the figures only the spectra for "fresh" DB fuel and fully burned DB fuel are shown.

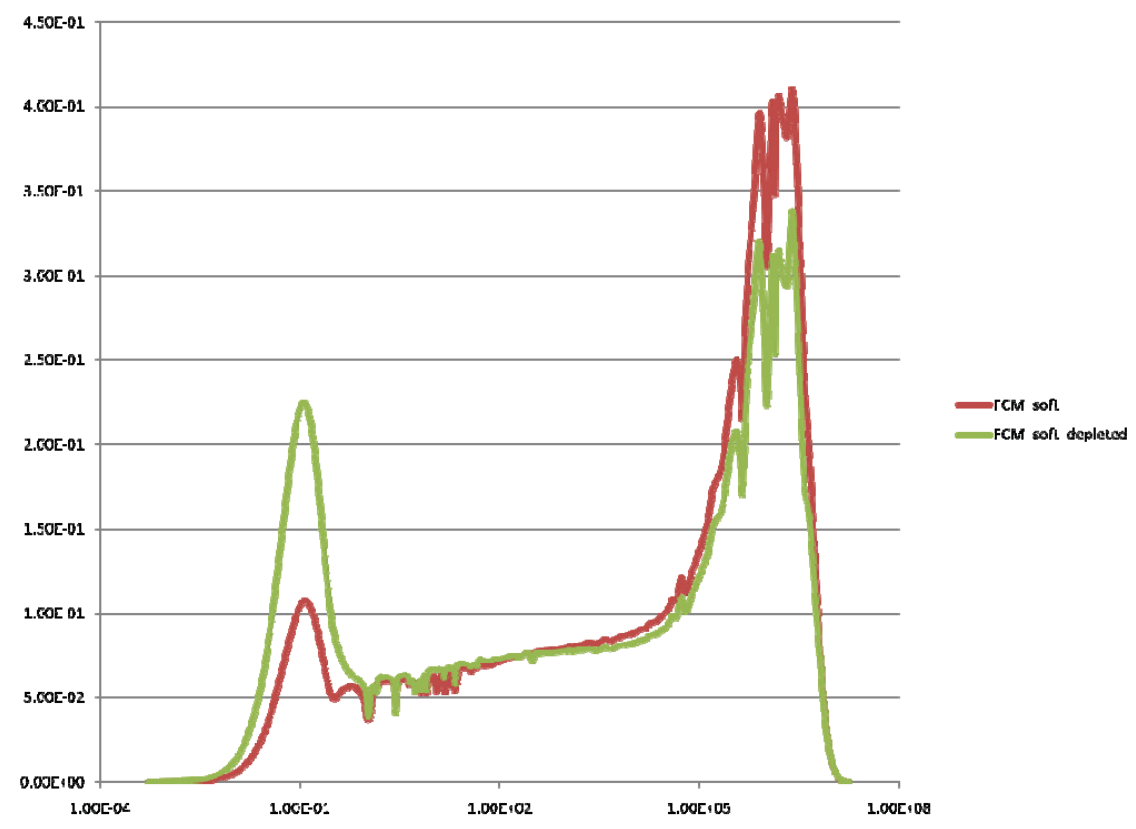

Figure 3: DB FCM soft spectrum (fresh and fully depleted)

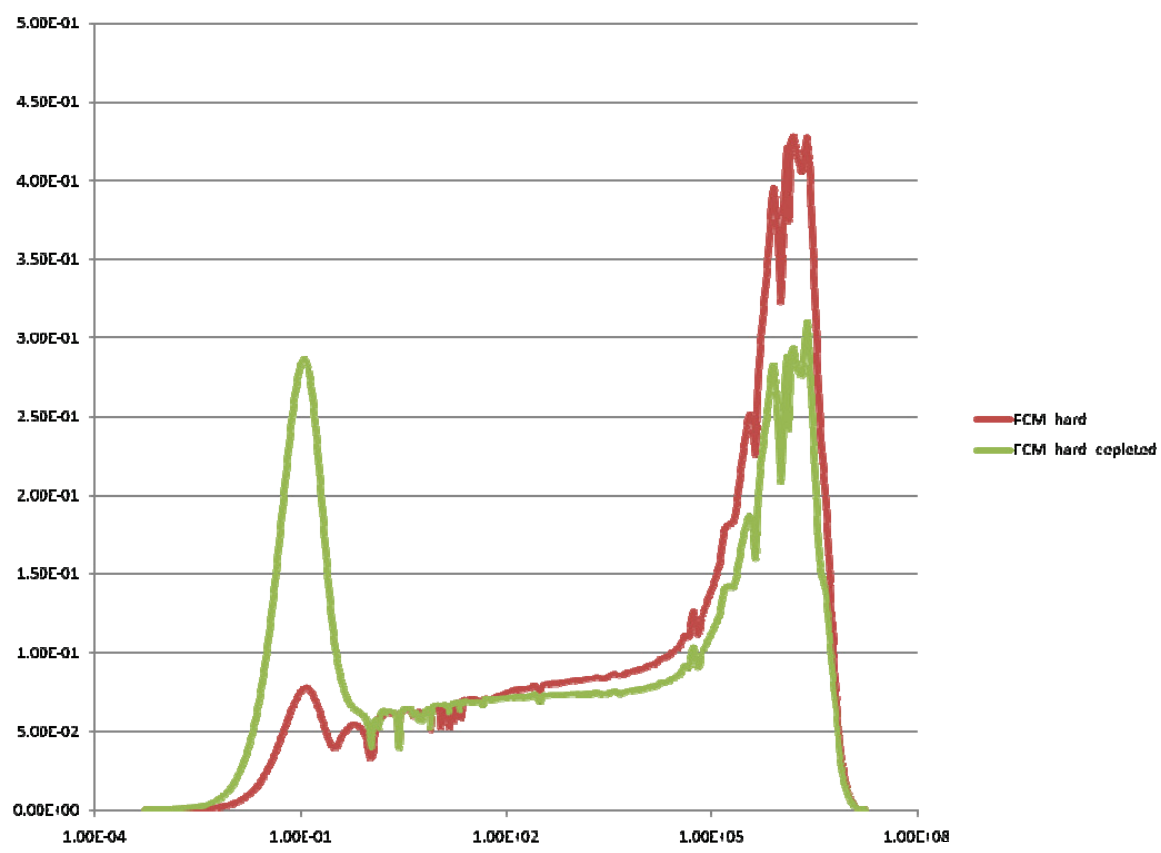

Figure 4: DB-FCM hard spectrum (fresh and fully depleted) 
For the cases of FCM fuel containing $\mathrm{UO}_{2}$ and $\mathrm{UN}$, only unit cell calculations were carried out. The geometry of these unit cells is evident from the data of Table 3-4. For these single cell cases, spectra and flux levels were also generated at each depletion step. The spectra for fresh and fully depleted cases are shown in Figure 5.

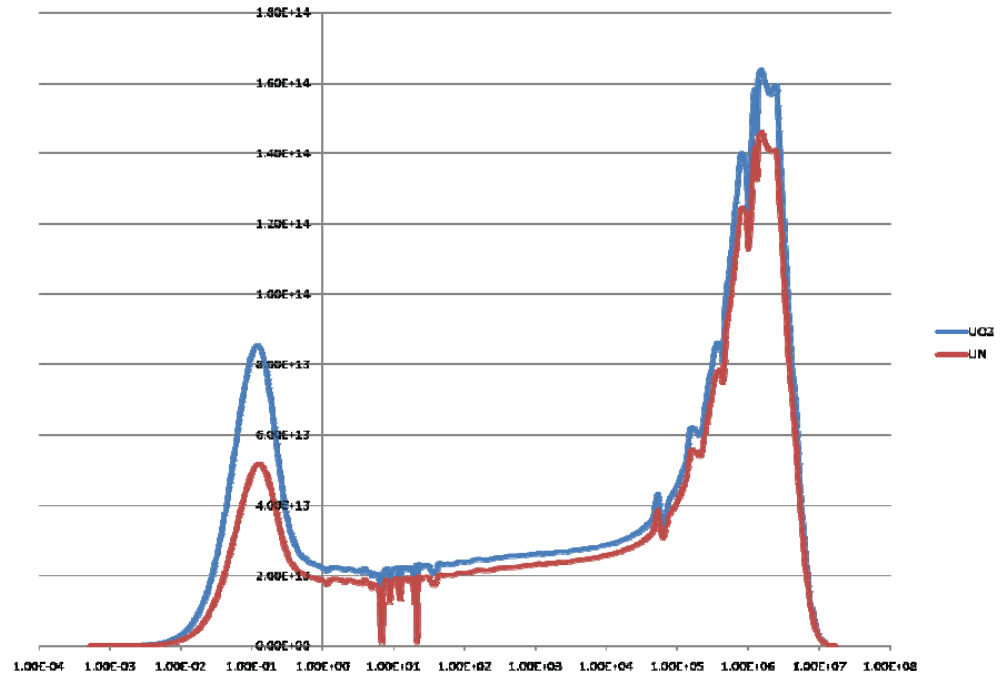

Figure 5: Spectra for fresh UO2 and UN-fueled FCM unit cells

\subsubsection{Fluences}

The duration the depletion steps in all cases considered in this study are shown in Table 4-1. Using these times and the flux levels, a simple multiplication provides the fluence for each depletion step, and an addition provides the total fluence at end of life for the fuel. The total fluences at EOL for the Softer TRUFCM case is $5.21 \mathrm{E}+22 \mathrm{n}-\mathrm{cm}^{-2}$ while for the Hard Spectrum case it is $5.94 \mathrm{E}+22 \mathrm{n}-\mathrm{cm}^{-2}$. It must be understood that the time steps defined in the table are for computational purposes only. In the DB-FCM cases full depletion is reached at the end of Step 48. In the case of the $\mathrm{UO}_{2} \mathrm{FCM}$ fuel, the reactor would go sub-critical and discharge would have to take place at the end of Step 30, while UN FCM fuel would last until the end of Step 37.

Table 4-1. Depletion time steps duration (sec)

\begin{tabular}{|c|c|c|c|c|c|c|c|}
\hline \multicolumn{7}{|c|}{ Standard Computational Depletion Steps Durations } \\
\hline Step & $\begin{array}{c}\text { Duration } \\
(\mathrm{sec})\end{array}$ & Step & $\begin{array}{c}\text { Duration } \\
(\mathrm{sec})\end{array}$ & Step & $\begin{array}{c}\text { Duration } \\
(\mathrm{sec})\end{array}$ & Step & $\begin{array}{c}\text { Duration } \\
(\mathrm{sec})\end{array}$ \\
\hline 1 & 43200 & 13 & 2160000 & 25 & 2160000 & 37 & 4320000 \\
\hline 2 & 43200 & 14 & 2160000 & 26 & 2160000 & 38 & 4320000 \\
\hline 3 & 86400 & 15 & 2160000 & 27 & 4320000 & 39 & 4320000 \\
\hline 4 & 259200 & 16 & 2160000 & 28 & 4320000 & 40 & 4320000 \\
\hline 5 & 432000 & 17 & 2160000 & 29 & 4320000 & 41 & 4320000 \\
\hline 6 & 432000 & 18 & 2160000 & 30 & 4320000 & 42 & 4320000 \\
\hline 7 & 432000 & 19 & 2160000 & 31 & 4320000 & 43 & 4320000 \\
\hline 8 & 864000 & 20 & 2160000 & 32 & 4320000 & 44 & 4320000 \\
\hline
\end{tabular}




\begin{tabular}{|c|c|c|c|c|c|c|c|}
\hline 9 & 1728000 & 21 & 2160000 & 33 & 4320000 & 45 & 4320000 \\
\hline 10 & 4320000 & 22 & 2160000 & 34 & 4320000 & 46 & 4320000 \\
\hline 11 & 2160000 & 23 & 2160000 & 35 & 4320000 & 47 & 4320000 \\
\hline 12 & 2160000 & 24 & 2160000 & 36 & 4320000 & 48 & 4320000 \\
\hline
\end{tabular}

\subsubsection{Displacement Kerma Cross Sections and NRT model}

The HEATR module within the NJOY code provides the facility for computing displacement kerma cross sections. The displacement kerma cross section is given by the product of the reaction cross section and the damage energy, which is the energy from the recoiling fragment that is available to cause atomic displacements in the lattice material, summed over all recoils and then over all reactions.

The damage energy is calculated by determining the emitted particles from the reaction, calculating the energy for each emitted particle, and then computing the fraction of this energy available to cause displacements in the lattice. This latter computation uses the Robinson version [15]of the Lindhard partition function [16] for each emitted particle. The Lindhard partition function is essentially a damage efficiency, describing the fraction of the particle energy available to cause atomic displacement damage in the lattice. It accounts for the effects of the differences in recoil particle and lattice atom electronic charges and masses on the damage energy. Conservation of energy is maintained for each reaction by assuring that the sum of the energies of the primary knock-on atom (PKA) and all emitted particles is equal to the sum of the incident neutron energy and the energy released by the reaction. The partition of the reaction energy between the PKA and emitted particles is determined by the kinematics of the particle emission. Details of the treatment of this partition are available elsewhere [17, 18,19,20,21].

The modified Kinchin-Pease model [22] of displacement damage, also referred to as the NRT model[15, is a widely accepted method for calculating damage in materials, especially metals. The model was originally formulated as a way to provide an expression for the number of displacements caused by a particle with damage energy E; however, it may be easily recast to provide an expression for the damage energy. When conforming to the NRT model, the equation for the damage energy is given by:

$$
E=\left\{\begin{array}{cl}
0, & E<E_{d} \\
2.5 E_{d}, & E_{d}<E<2.5 E_{d} \\
E, & E \geq 2.5 E_{d}
\end{array}\right.
$$

where $E_{d}$ is the average threshold energy for displacement and where is $E$ on the right side is given by the Lindhard (or the Robinson) energy partition function. It is this form that is implemented in the modified NJOY99, and applied to each PKA and emitted particle from all reactions.

For a binary compound such as $\mathrm{SiC}$, one can compute the displacement kerma cross sections of the sublattices assuming the primary-knock-on atom is either $\mathrm{Si}$ or $\mathrm{C}$ and that that atom then interacts with either the $\mathrm{C}$ or the $\mathrm{Si}$ sub-lattice. There results four tables of displacement kerma cross sections that are then combined with a weight of 0.25 each. The displacement kerma cross section for the compound, that is $\mathrm{SiC}$ here, normalized for the $E_{d}$ values per the NRT model is shown in Figure $\mathbf{6}$ as the dpa cross section versus energy. The actual tabulation for this damage function was actually computed in 640 fine energy groups. The value of the displacement threshold energy varies depending on which atom is incident on which sublattice. In this work, a value of $35 \mathrm{eV}$ is used for $\mathrm{C}$ incident on $\mathrm{C}$ or on $\mathrm{Si}, 25 \mathrm{eV}$ is used for $\mathrm{Si}$ incident on $\mathrm{Si}$, and $20 \mathrm{eV}$ is used for Si incident on $\mathrm{C}$ [23]. 


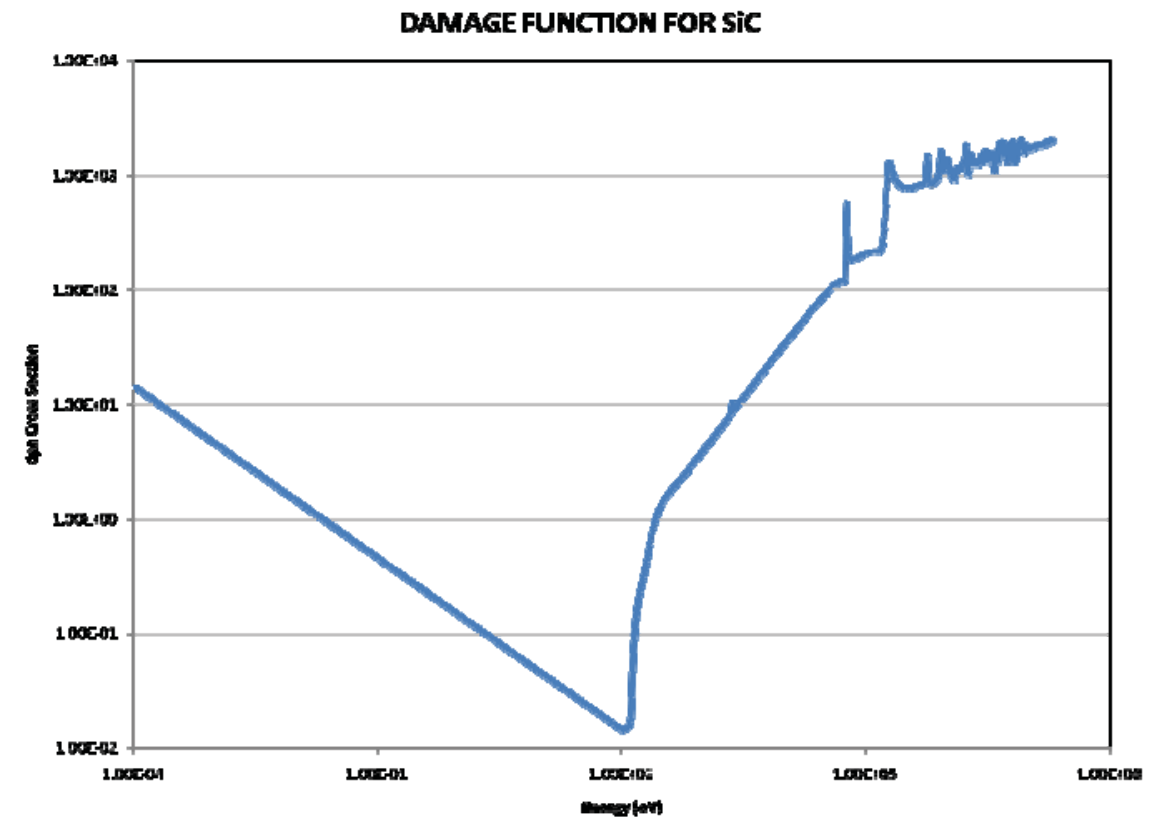

Figure 6: Displacement damage cross section for $\mathrm{SiC}$ (dpa per unit fluence)

\subsubsection{Total dpa at each depletion step and at full burnup}

Using the methodology explained above, one obtains estimates for the number of displacements per atom (dpa). The dpa values have been computed for each depletion time step of the DB-FCM fuels and the cumulative dpa as a function of burnup (i.e., advancing time) have been computed as sunning sums. As an example, the cumulative dpa for the softer cell case is shown in Figure 7. The total dpa value at full burnup for the softer DB-FCM case is $112 \mathrm{dpa}$, while for the harder DB-FCM case it is $127 \mathrm{dpa}$. 


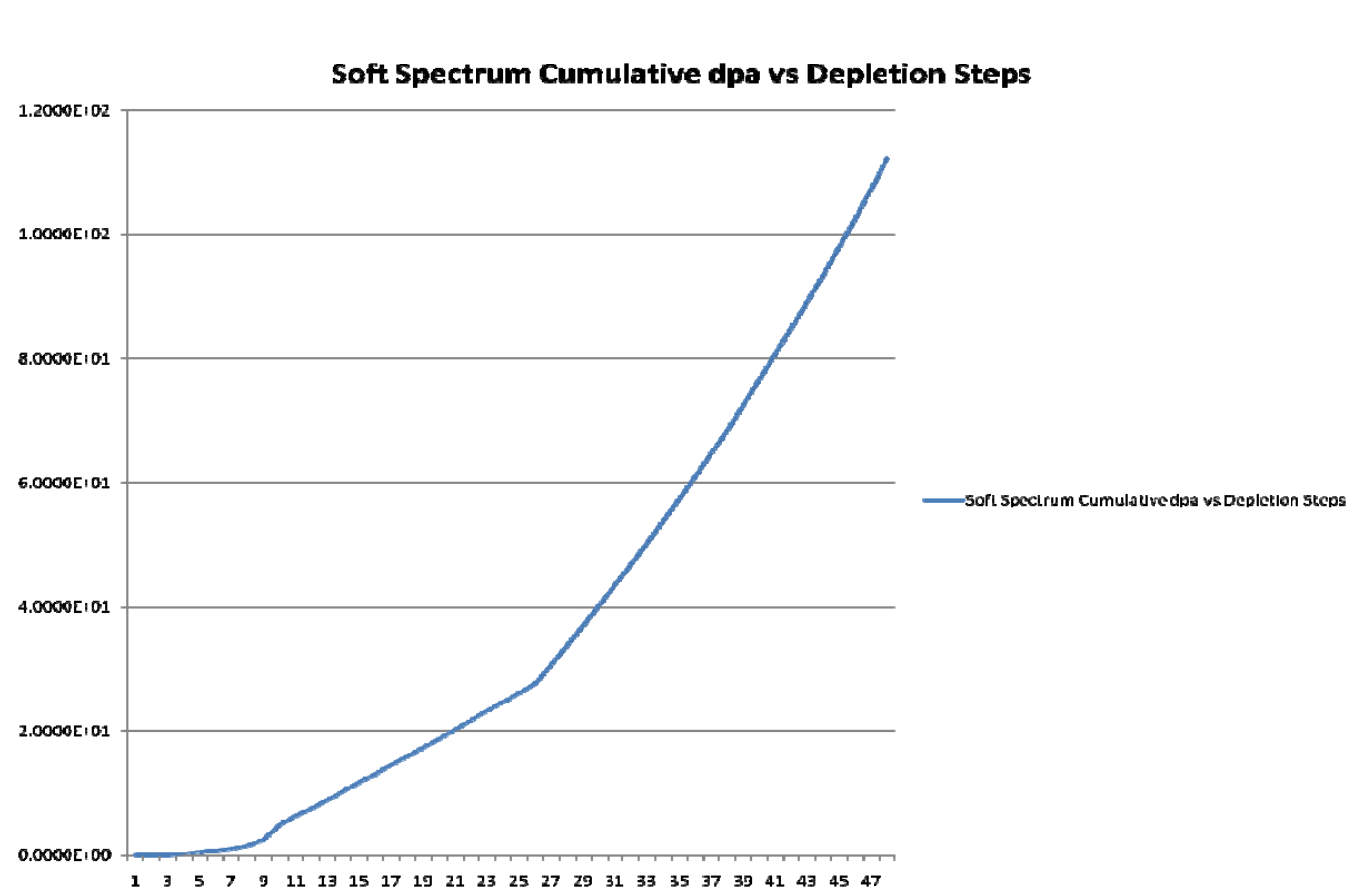

Figure 7: Cumulative dpa versus depletion time step (softer DB-FCM case)

\subsection{Computing ATR experimental fluences}

The fluence rates in ATR in the various irradiation facilities are known and published values. So are the spectra at those locations. Evaluation of total experimental fluences reduces, therefore, to measuring time and keeping track of power levels. In this section this information is used in conjunction with the dpa cross section to predict needed irradiation times (assuming full power operations).

\subsubsection{Spectra and flux levels in ATR}

The irradiation facilities of the ATR have been extensively characterized by JW Rogers and R. A. Anderl [INEL-95/0494, ATR Neutron Spectral Characterization, Idaho National Engineering Laboratory, November 1995]. In this work, the spectra and flux levels from that reference are used unchanged. When folding the spectra, NRT-modified displacement kerma cross sections and flux levels, a dpa production rate is obtained. In Table 4-2, all of these data are summarized for fifteen (15) irradiation locations in the ATR. The last line in the table contains the rate of dpa production. 
Table 4-2: Energy-group flux levels, total flux levels and damage production rates for $\mathrm{SiC}$ in ATR irradiation facilities

ATR IRRADIATION LOCATION

\begin{tabular}{|c|c|c|c|c|c|c|c|c|c|c|c|c|c|c|c|}
\hline $\begin{array}{c}\text { Group } \\
\text { Upper } \\
\text { Energy } \\
\text { Boundary } \\
\text { (eV) }\end{array}$ & A-1 & A-10 & A-12 & B-1 & B-8 & B-11 & $\mathrm{H}-2$ & H-10 & H-14 & I-6 & $1-8$ & $1-22$ & OS-5 & SE-1 & SE-3 \\
\hline $4.14 \mathrm{E}-01$ & $1.57 \mathrm{E}+13$ & $1.57 E+13$ & $1.57 \mathrm{E}+13$ & $1.57 \mathrm{E}+13$ & $1.57 E+13$ & $7.84 \mathrm{E}+12$ & $1.57 E+13$ & $1.57 E+13$ & $1.57 \mathrm{E}+13$ & $9.41 \mathrm{E}+11$ & $1.26 \mathrm{E}+12$ & $1.57 \mathrm{E}+12$ & $9.41 \mathrm{E}+10$ & $1.57 E+13$ & $1.57 \mathrm{E}+13$ \\
\hline $5.32 \mathrm{E}-01$ & $6.34 \mathrm{E}+11$ & $6.76 \mathrm{E}+11$ & $6.29 \mathrm{E}+11$ & $5.75 \mathrm{E}+11$ & $5.23 \mathrm{E}+11$ & $2.22 \mathrm{E}+11$ & $6.18 E+11$ & $6.81 \mathrm{E}+11$ & $6.22 E+11$ & $3.33 \mathrm{E}+10$ & $3.63 E+10$ & $5.10 \mathrm{E}+10$ & $3.49 E+09$ & $6.07 E+11$ & $6.50 \mathrm{E}+11$ \\
\hline $1.13 E+00$ & $1.81 \mathrm{E}+12$ & $1.94 \mathrm{E}+12$ & $1.80 \mathrm{E}+12$ & $1.66 \mathrm{E}+12$ & $1.52 \mathrm{E}+12$ & $6.64 \mathrm{E}+11$ & $1.79 E+12$ & $1.98 \mathrm{E}+12$ & $1.79 E+12$ & $1.03 \mathrm{E}+11$ & $1.11 \mathrm{E}+11$ & $1.58 \mathrm{E}+11$ & $1.09 E+10$ & $1.75 E+12$ & $1.88 \mathrm{E}+12$ \\
\hline $1.86 \mathrm{E}+00$ & 1. $19 \mathrm{E}+12$ & $1.27 \mathrm{E}+12$ & 1.19E+12 & $1.09 \mathrm{E}+12$ & $9.94 E+11$ & $4.53 E+11$ & $1.19 \mathrm{E}+12$ & $1.30 \mathrm{E}+12$ & $1.18 \mathrm{E}+12$ & $6.76 \mathrm{E}+10$ & $7.59 \mathrm{E}+10$ & $1.07 E+11$ & $7.23 E+09$ & 1.13E+12 & $1.23 \mathrm{E}+12$ \\
\hline $3.06 巨+00$ & 1.20E+12 & 1.27E+12 & 1. $19 \mathrm{E}+12$ & $1.09 E+12$ & $9.97 E+11$ & $4.77 E+11$ & $1.21 \mathrm{E}+12$ & $1.30 \mathrm{E}+12$ & 1.19E+12 & $6.77 E+10$ & $7.94 \mathrm{E}+10$ & 1.11E+11 & $7.29 E+09$ & 1. $13 \mathrm{E}+12$ & 1.23E+12 \\
\hline $3.93 E+00$ & $6.11 \mathrm{E}+11$ & $6.37 E+11$ & $5.97 \mathrm{E}+11$ & $5.36 \mathrm{E}+11$ & $4.99 \mathrm{E}+11$ & $2.53 E+11$ & $6.14 E+11$ & $6.49 \mathrm{E}+11$ & $6.04 E+11$ & $3.32 \mathrm{E}+10$ & $4.12 E+10$ & $5.72 E+10$ & $3.57 \mathrm{E}+09$ & $5.58 \mathrm{E}+11$ & $6.17 \mathrm{E}+11$ \\
\hline $6.48 E+00$ & $1.17 \mathrm{E}+12$ & 1.22E+12 & $1.17 \mathrm{E}+12$ & $1.04 \mathrm{E}+12$ & $9.40 E+11$ & $5.05 \mathrm{E}+11$ & 1. $18 \mathrm{E}+12$ & 1.22E+12 & 1.16E+12 & $6.04 \mathrm{E}+10$ & $8.06 \mathrm{E}+10$ & $1.06 \mathrm{E}+11$ & $6.59 E+09$ & $1.04 \mathrm{E}+12$ & $1.17 \mathrm{E}+12$ \\
\hline $2.90 \mathrm{E}+01$ & $3.99 \mathrm{E}+12$ & $4.03 \mathrm{E}+12$ & $3.66 \mathrm{E}+12$ & 3.19E+12 & $3.11 \mathrm{E}+12$ & $1.80 \mathrm{E}+12$ & $3.96 \mathrm{E}+12$ & $4.11 \mathrm{E}+12$ & $3.89 \mathrm{E}+12$ & $2.03 E+11$ & $2.77 \mathrm{E}+11$ & $3.88 \mathrm{E}+11$ & $2.16 \mathrm{E}+10$ & $3.46 \mathrm{E}+12$ & $3.89 \mathrm{E}+12$ \\
\hline $1.01 \mathrm{E}+02$ & $3.39 \mathrm{E}+12$ & $3.40 \mathrm{E}+12$ & $3.14 \mathrm{E}+12$ & $2.72 E+12$ & $2.58 \mathrm{E}+12$ & $1.50 \mathrm{E}+12$ & $3.36 \mathrm{E}+12$ & $3.42 \mathrm{E}+12$ & $3.32 \mathrm{E}+12$ & $1.63 \mathrm{E}+11$ & $2.25 E+11$ & $3.06 \mathrm{E}+11$ & $1.70 E+10$ & $2.91 E+12$ & $3.25 \mathrm{E}+12$ \\
\hline $2.14 \mathrm{E}+02$ & $2.01 \mathrm{E}+12$ & $1.95 E+12$ & $1.99 \mathrm{E}+12$ & $1.71 \mathrm{E}+12$ & $1.48 \mathrm{E}+12$ & $8.09 \mathrm{E}+11$ & $2.04 E+12$ & $1.94 \mathrm{E}+12$ & $2.00 E+12$ & $8.98 E+10$ & $1.25 \mathrm{E}+11$ & $1.63 E+11$ & $9.05 E+09$ & $1.73 E+12$ & $1.89 \mathrm{E}+12$ \\
\hline $2.75 E+02$ & $7.08 \mathrm{E}+11$ & $7.10 \mathrm{E}+11$ & $6.68 \mathrm{E}+11$ & $5.86 \mathrm{E}+11$ & $5.14 \mathrm{E}+11$ & $2.93 E+11$ & $6.86 \mathrm{E}+11$ & $7.05 E+11$ & $6.92 E+11$ & 3.19E+10 & $4.23 E+10$ & $5.48 \mathrm{E}+10$ & $3.21 \mathrm{E}+09$ & $6.10 \mathrm{E}+11$ & $6.67 \mathrm{E}+11$ \\
\hline $4.54 \mathrm{E}+02$ & $1.44 \mathrm{E}+12$ & $1.47 E+12$ & $1.36 \mathrm{E}+12$ & $1.22 \mathrm{E}+12$ & $1.02 E+12$ & $5.88 \mathrm{E}+11$ & $1.37 \mathrm{E}+12$ & $1.45 \mathrm{E}+12$ & $1.41 \mathrm{E}+12$ & $6.52 \mathrm{E}+10$ & $8.21 \mathrm{E}+10$ & $1.04 \mathrm{E}+11$ & $6.48 E+09$ & $1.26 \mathrm{E}+12$ & $1.36 \mathrm{E}+12$ \\
\hline $1.23 E+03$ & $2.87 \mathrm{E}+12$ & $2.91 \mathrm{E}+12$ & $2.69 \mathrm{E}+12$ & $2.34 \mathrm{E}+12$ & $2.05 E+12$ & $1.11 \mathrm{E}+12$ & $2.70 E+12$ & $2.84 \mathrm{E}+12$ & $2.79 E+12$ & $1.21 \mathrm{E}+11$ & $1.54 E+11$ & $1.96 \mathrm{E}+11$ & $1.19 \mathrm{E}+10$ & $2.49 \mathrm{E}+12$ & $2.69 \mathrm{E}+12$ \\
\hline $5.53 E+03$ & $4.48 \mathrm{E}+12$ & $4.58 \mathrm{E}+12$ & $4.20 \mathrm{E}+12$ & $3.64 \mathrm{E}+12$ & 3.19E+12 & $1.67 E+12$ & $4.15 \mathrm{E}+12$ & $4.42 E+12$ & $4.35 E+12$ & $1.82 E+11$ & $2.27 \mathrm{E}+11$ & $2.89 \mathrm{E}+11$ & $1.78 E+10$ & $3.90 \mathrm{E}+12$ & $4.20 \mathrm{E}+12$ \\
\hline $9.12 E+03$ & $1.45 \mathrm{E}+12$ & $1.49 \mathrm{E}+12$ & $1.37 \mathrm{E}+12$ & $1.17 \mathrm{E}+12$ & $1.04 \mathrm{E}+12$ & $5.22 \mathrm{E}+11$ & $1.33 E+12$ & $1.43 \mathrm{E}+12$ & $1.41 \mathrm{E}+12$ & $5.69 \mathrm{E}+10$ & $6.95 E+10$ & $8.84 \mathrm{E}+10$ & $5.54 E+09$ & $1.27 \mathrm{E}+12$ & $1.36 \mathrm{E}+12$ \\
\hline $1.50 \mathrm{E}+04$ & $1.55 \mathrm{E}+12$ & $1.61 \mathrm{E}+12$ & $1.47 \mathrm{E}+12$ & $1.23 \mathrm{E}+12$ & $1.11 \mathrm{E}+12$ & $5.40 \mathrm{E}+11$ & $1.40 \mathrm{E}+12$ & $1.51 \mathrm{E}+12$ & $1.51 \mathrm{E}+12$ & $5.82 \mathrm{E}+10$ & $7.05 E+10$ & $8.98 \mathrm{E}+10$ & $5.66 \mathrm{E}+09$ & $1.35 \mathrm{E}+12$ & $1.46 \mathrm{E}+12$ \\
\hline $2.48 \mathrm{E}+04$ & $1.60 \mathrm{E}+12$ & 1.66E+12 & $1.52 \mathrm{E}+12$ & 1.23E+12 & $1.14 \mathrm{E}+12$ & $5.37 E+11$ & $1.44 \mathrm{E}+12$ & $1.54 \mathrm{E}+12$ & $1.57 \mathrm{E}+12$ & $5.65 E+10$ & $6.87 E+10$ & $8.80 \mathrm{E}+10$ & $5.50 E+09$ & $1.39 \mathrm{E}+12$ & $1.50 \mathrm{E}+12$ \\
\hline $5.25 \mathrm{E}+04$ & 2.46E+12 & $2.55 \mathrm{E}+12$ & 2.34E+12 & $1.84 \mathrm{E}+12$ & $1.74 \mathrm{E}+12$ & $7.91 \mathrm{E}+11$ & $2.20 \mathrm{E}+12$ & $2.32 E+12$ & $2.41 \mathrm{E}+12$ & 8.07E+10 & $9.86 \mathrm{E}+10$ & 1.27E+11 & $7.85 E+09$ & $2.11 \mathrm{E}+12$ & 2.29E+12 \\
\hline $1.11 E+05$ & $2.83 E+12$ & $2.94 \mathrm{E}+12$ & $2.71 \mathrm{E}+12$ & $2.06 \mathrm{E}+12$ & $1.97 E+12$ & $8.65 E+11$ & $2.53 E+12$ & $2.62 E+12$ & $2.77 \mathrm{E}+12$ & $8.49 \mathrm{E}+10$ & $1.05 E+11$ & $1.35 E+11$ & $8.28 E+09$ & $2.40 \mathrm{E}+12$ & $2.62 \mathrm{E}+12$ \\
\hline $3.02 E+05$ & $5.19 \mathrm{E}+12$ & $5.39 \mathrm{E}+12$ & $4.99 \mathrm{E}+12$ & 3.65E+12 & $3.52 E+12$ & $1.48 \mathrm{E}+12$ & $4.64 \mathrm{E}+12$ & $4.71 \mathrm{E}+12$ & $5.05 \mathrm{E}+12$ & $1.39 \mathrm{E}+11$ & $1.75 \mathrm{E}+11$ & $2.25 \mathrm{E}+11$ & $1.36 \mathrm{E}+10$ & $4.34 \mathrm{E}+12$ & $4.76 \mathrm{E}+12$ \\
\hline $4.98 \mathrm{E}+05$ & $4.03 E+12$ & $4.21 \mathrm{E}+12$ & $3.91 \mathrm{E}+12$ & $2.75 E+12$ & $2.64 \mathrm{E}+12$ & $1.06 \mathrm{E}+12$ & $3.61 \mathrm{E}+12$ & $3.60 \mathrm{E}+12$ & $3.88 \mathrm{E}+12$ & $9.41 \mathrm{E}+10$ & $1.22 \mathrm{E}+11$ & $1.56 \mathrm{E}+11$ & $9.19 \mathrm{E}+09$ & $3.32 \mathrm{E}+12$ & $3.66 \mathrm{E}+12$ \\
\hline $8.21 E+05$ & $5.48 \mathrm{E}+12$ & $5.76 \mathrm{E}+12$ & $5.36 \mathrm{E}+12$ & $3.60 \mathrm{E}+12$ & $3.44 \mathrm{E}+12$ & $1.30 \mathrm{E}+12$ & $4.87 \mathrm{E}+12$ & $4.81 \mathrm{E}+12$ & $5.24 E+12$ & $1.09 \mathrm{E}+11$ & $1.44 \mathrm{E}+11$ & $1.84 \mathrm{E}+11$ & $1.06 E+10$ & $4.42 E+12$ & $4.93 \mathrm{E}+12$ \\
\hline $1.00 E+06$ & $2.40 \mathrm{E}+12$ & $2.56 \mathrm{E}+12$ & $2.37 \mathrm{E}+12$ & $1.54 \mathrm{E}+12$ & $1.44 \mathrm{E}+12$ & $4.99 \mathrm{E}+11$ & $2.14 E+12$ & $2.10 \mathrm{E}+12$ & $2.23 E+12$ & $4.02 E+10$ & $5.49 E+10$ & $6.96 \mathrm{E}+10$ & $3.87 E+09$ & $1.90 \mathrm{E}+12$ & $2.14 E+12$ \\
\hline $1.50 E+06$ & $5.11 \mathrm{E}+12$ & $5.50 E+12$ & $5.07 E+12$ & 3.18E+12 & $2.90 \mathrm{E}+12$ & $9.22 E+11$ & $4.51 E+12$ & $4.45 \mathrm{E}+12$ & $4.62 E+12$ & $7.06 \mathrm{E}+10$ & $9.93 E+10$ & $1.25 \mathrm{E}+11$ & $6.69 E+09$ & $3.97 E+12$ & $4.49 E+12$ \\
\hline $2.00 E+06$ & $3.57 \mathrm{E}+12$ & $3.92 E+12$ & $3.53 \mathrm{E}+12$ & $2.18 \mathrm{E}+12$ & $1.90 \mathrm{E}+12$ & $5.51 \mathrm{E}+11$ & $3.24 E+12$ & $3.07 E+12$ & $3.05 E+12$ & $4.04 \mathrm{E}+10$ & $5.93 E+10$ & $7.33 E+10$ & $3.84 E+09$ & $2.74 \mathrm{E}+12$ & $3.08 \mathrm{E}+12$ \\
\hline $2.50 E+06$ & $2.69 \mathrm{E}+12$ & $2.97 E+12$ & $2.67 \mathrm{E}+12$ & $1.60 E+12$ & $1.37 E+12$ & $3.56 \mathrm{E}+11$ & $2.29 \mathrm{E}+12$ & $2.40 \mathrm{E}+12$ & $2.24 \mathrm{E}+12$ & $2.60 E+10$ & $3.84 \mathrm{E}+10$ & $4.82 E+10$ & $2.33 E+09$ & $2.01 E+12$ & $2.30 \mathrm{E}+12$ \\
\hline $3.00 E+06$ & $1.93 E+12$ & $2.14 \mathrm{E}+12$ & $1.92 \mathrm{E}+12$ & $1.10 \mathrm{E}+12$ & $9.53 E+11$ & $2.27 \mathrm{E}+11$ & $1.58 \mathrm{E}+12$ & $1.69 \mathrm{E}+12$ & $1.62 E+12$ & $1.68 \mathrm{E}+10$ & $2.44 \mathrm{E}+10$ & $3.08 \mathrm{E}+10$ & $1.44 \mathrm{E}+09$ & $1.40 \mathrm{E}+12$ & $1.65 \mathrm{E}+12$ \\
\hline
\end{tabular}




\begin{tabular}{|c|c|c|c|c|c|c|c|c|c|c|c|c|c|c|c|}
\hline $\begin{array}{c}\text { Group } \\
\text { Upper } \\
\text { Energy } \\
\text { Boundary } \\
\text { (eV) }\end{array}$ & A-1 & A-10 & A-12 & B-1 & B-8 & B-11 & $\mathrm{H}-2$ & H-10 & H-14 & $1-6$ & $1-8$ & $1-22$ & OS-5 & SE-1 & SE-3 \\
\hline $3.50 \mathrm{E}+06$ & $1.30 \mathrm{E}+12$ & $1.42 E+12$ & $1.28 \mathrm{E}+12$ & $7.03 E+11$ & $6.17 \mathrm{E}+11$ & $1.40 \mathrm{E}+11$ & $1.02 E+12$ & $1.12 \mathrm{E}+12$ & $1.07 \mathrm{E}+12$ & $1.05 E+10$ & $1.50 \mathrm{E}+10$ & $1.90 E+10$ & $8.77 E+08$ & $9.15 \mathrm{E}+11$ & $1.09 \mathrm{E}+12$ \\
\hline $4.00 E+06$ & $9.09 E+11$ & $9.73 E+11$ & $8.75 E+11$ & $4.70 E+11$ & $4.18 \mathrm{E}+11$ & $9.34 \mathrm{E}+10$ & $6.94 \mathrm{E}+11$ & $7.65 E+11$ & $7.33 E+11$ & $7.20 \mathrm{E}+09$ & $9.93 E+09$ & $1.27 \mathrm{E}+10$ & $5.88 \mathrm{E}+08$ & $6.32 \mathrm{E}+11$ & $7.41 \mathrm{E}+11$ \\
\hline $4.50 \mathrm{E}+06$ & $6.67 \mathrm{E}+11$ & $6.96 \mathrm{E}+11$ & $6.28 \mathrm{E}+11$ & $3.29 \mathrm{E}+11$ & $2.97 \mathrm{E}+11$ & $6.69 \mathrm{E}+10$ & $5.02 E+11$ & $5.41 \mathrm{E}+11$ & $5.24 E+11$ & $5.31 \mathrm{E}+09$ & $7.08 \mathrm{E}+09$ & $9.04 E+09$ & $4.34 \mathrm{E}+08$ & $4.59 \mathrm{E}+11$ & $5.24 \mathrm{E}+11$ \\
\hline $5.00 \mathrm{E}+06$ & $4.98 \mathrm{E}+11$ & $5.09 \mathrm{E}+11$ & $4.61 \mathrm{E}+11$ & $2.38 \mathrm{E}+11$ & $2.18 \mathrm{E}+11$ & $4.99 E+10$ & $3.75 E+11$ & $3.92 E+11$ & $3.81 E+11$ & $4.11 \mathrm{E}+09$ & $5.32 \mathrm{E}+09$ & $6.75 E+09$ & $3.42 E+08$ & $3.44 \mathrm{E}+11$ & $3.78 \mathrm{E}+11$ \\
\hline $5.50 \mathrm{E}+06$ & $3.62 E+11$ & $3.66 \mathrm{E}+11$ & $3.32 \mathrm{E}+11$ & $1.70 \mathrm{E}+11$ & $1.58 \mathrm{E}+11$ & $3.68 \mathrm{E}+10$ & $2.74 E+11$ & $2.80 \mathrm{E}+11$ & $2.71 \mathrm{E}+11$ & $3.15 \mathrm{E}+09$ & $3.99 E+09$ & $5.03 E+09$ & $2.72 E+08$ & $2.53 E+11$ & $2.66 \mathrm{E}+11$ \\
\hline $6.00 \mathrm{E}+06$ & $2.53 \mathrm{E}+11$ & $2.56 \mathrm{E}+11$ & $2.32 \mathrm{E}+11$ & $1.20 \mathrm{E}+11$ & $1.12 \mathrm{E}+11$ & $2.65 E+10$ & $1.93 E+11$ & $1.96 \mathrm{E}+11$ & $1.87 E+11$ & $2.36 \mathrm{E}+09$ & $2.94 \mathrm{E}+09$ & $3.69 E+09$ & $2.12 E+08$ & $1.79 E+11$ & $1.84 \mathrm{E}+11$ \\
\hline $6.50 \mathrm{E}+06$ & $1.74 E+11$ & $1.76 \mathrm{E}+11$ & $1.61 \mathrm{E}+11$ & $8.46 \mathrm{E}+10$ & $7.78 \mathrm{E}+10$ & $1.88 E+10$ & $1.33 E+11$ & $1.35 \mathrm{E}+11$ & $1.28 \mathrm{E}+11$ & $1.72 E+09$ & $2.14 \mathrm{E}+09$ & $2.68 \mathrm{E}+09$ & $1.61 E+08$ & $1.23 E+11$ & $1.26 \mathrm{E}+11$ \\
\hline $7.00 \mathrm{E}+06$ & $1.18 \mathrm{E}+11$ & $1.21 \mathrm{E}+11$ & $1.11 \mathrm{E}+11$ & $6.00 \mathrm{E}+10$ & $5.43 \mathrm{E}+10$ & $1.33 E+10$ & $9.15 \mathrm{E}+10$ & $9.29 \mathrm{E}+10$ & $8.76 \mathrm{E}+10$ & $1.24 \mathrm{E}+09$ & $1.56 \mathrm{E}+09$ & $1.96 \mathrm{E}+09$ & $1.19 \mathrm{E}+08$ & $8.34 \mathrm{E}+10$ & $8.73 E+10$ \\
\hline $7.50 \mathrm{E}+06$ & $7.97 E+10$ & $8.33 E+10$ & $7.65 E+10$ & $4.28 \mathrm{E}+10$ & $3.80 \mathrm{E}+10$ & $9.42 E+09$ & $6.25 E+10$ & $6.40 \mathrm{E}+10$ & $6.03 E+10$ & $8.90 E+08$ & 1.14E+09 & $1.44 E+09$ & $8.72 E+07$ & $5.60 E+10$ & $6.09 \mathrm{E}+10$ \\
\hline $8.00 E+06$ & $5.34 E+10$ & $5.69 \mathrm{E}+10$ & $5.24 E+10$ & $3.05 E+10$ & $2.67 E+10$ & $6.68 \mathrm{E}+09$ & $4.24 \mathrm{E}+10$ & 4.40E+10 & $4.15 \mathrm{E}+10$ & $6.37 \mathrm{E}+08$ & $8.31 \mathrm{E}+08$ & $1.06 \mathrm{E}+09$ & $6.30 \mathrm{E}+07$ & $3.75 \mathrm{E}+10$ & $4.24 \mathrm{E}+10$ \\
\hline $8.50 \mathrm{E}+06$ & $3.54 E+10$ & $3.84 \mathrm{E}+10$ & $3.55 \mathrm{E}+10$ & $2.16 \mathrm{E}+10$ & $1.86 \mathrm{E}+10$ & $4.71 E+09$ & $2.86 \mathrm{E}+10$ & $3.01 \mathrm{E}+10$ & $2.83 E+10$ & $4.54 \mathrm{E}+08$ & $6.04 E+08$ & $7.74 E+08$ & $4.53 E+07$ & $2.51 \mathrm{E}+10$ & $2.92 \mathrm{E}+10$ \\
\hline $9.00 \mathrm{E}+06$ & $2.33 \mathrm{E}+10$ & $2.56 \mathrm{E}+10$ & $2.38 \mathrm{E}+10$ & $1.50 \mathrm{E}+10$ & $1.29 \mathrm{E}+10$ & $3.31 \mathrm{E}+09$ & $1.91 \mathrm{E}+10$ & $2.03 E+10$ & $1.91 \mathrm{E}+10$ & $3.23 \mathrm{E}+08$ & $4.36 \mathrm{E}+08$ & $5.62 E+08$ & $3.23 E+07$ & $1.67 E+10$ & $1.99 \mathrm{E}+10$ \\
\hline $9.50 \mathrm{E}+06$ & $1.53 E+10$ & $1.69 \mathrm{E}+10$ & $1.58 \mathrm{E}+10$ & $1.04 E+10$ & $8.89 E+09$ & $2.34 E+09$ & $1.27 \mathrm{E}+10$ & $1.37 \mathrm{E}+10$ & $1.29 E+10$ & $2.31 E+08$ & $3.14 \mathrm{E}+08$ & $4.07 E+08$ & $2.30 E+07$ & $1.11 \mathrm{E}+10$ & $1.35 \mathrm{E}+10$ \\
\hline $1.00 \mathrm{E}+07$ & $1.00 E+10$ & $1.12 \mathrm{E}+10$ & $1.04 E+10$ & $7.14 E+09$ & $6.12 \mathrm{E}+09$ & $1.67 \mathrm{E}+09$ & $8.40 E+09$ & $9.25 E+09$ & $8.72 E+09$ & $1.66 \mathrm{E}+08$ & $2.27 \mathrm{E}+08$ & $2.96 \mathrm{E}+08$ & $1.64 \mathrm{E}+07$ & $7.44 \mathrm{E}+09$ & $9.09 \mathrm{E}+09$ \\
\hline $1.05 \mathrm{E}+07$ & $6.68 \mathrm{E}+09$ & $7.41 E+09$ & $6.95 \mathrm{E}+09$ & $4.93 E+09$ & $4.24 E+09$ & 1.20E+09 & $5.63 \mathrm{E}+09$ & $6.28 \mathrm{E}+09$ & $5.94 \mathrm{E}+09$ & $1.21 \mathrm{E}+08$ & $1.65 E+08$ & $2.16 \mathrm{E}+08$ & $1.18 \mathrm{E}+07$ & $5.05 \mathrm{E}+09$ & $6.18 \mathrm{E}+09$ \\
\hline $1.10 \mathrm{E}+07$ & $4.56 \mathrm{E}+09$ & $5.02 E+09$ & $4.73 E+09$ & $3.46 \mathrm{E}+09$ & $3.00 \mathrm{E}+09$ & $8.86 \mathrm{E}+08$ & $3.86 \mathrm{E}+09$ & $4.36 \mathrm{E}+09$ & $4.14 E+09$ & $9.01 E+07$ & $1.22 \mathrm{E}+08$ & $1.61 E+08$ & $8.73 E+06$ & $3.52 E+09$ & $4.28 \mathrm{E}+09$ \\
\hline $1.15 \mathrm{E}+07$ & $3.17 E+09$ & $3.46 \mathrm{E}+09$ & $3.27 \mathrm{E}+09$ & $2.45 \mathrm{E}+09$ & $2.14 E+09$ & $6.63 \mathrm{E}+08$ & $2.70 \mathrm{E}+09$ & $3.06 \mathrm{E}+09$ & $2.92 \mathrm{E}+09$ & $6.80 \mathrm{E}+07$ & $9.13 \mathrm{E}+07$ & $1.21 \mathrm{E}+08$ & $6.51 E+06$ & $2.49 \mathrm{E}+09$ & $3.01 \mathrm{E}+09$ \\
\hline $1.20 \mathrm{E}+07$ & $2.21 \mathrm{E}+09$ & $2.39 \mathrm{E}+09$ & $2.26 \mathrm{E}+09$ & $1.74 E+09$ & $1.53 \mathrm{E}+09$ & $4.95 E+08$ & $1.89 \mathrm{E}+09$ & $2.15 \mathrm{E}+09$ & $2.06 \mathrm{E}+09$ & $5.12 \mathrm{E}+07$ & $6.81 \mathrm{E}+07$ & $9.05 E+07$ & $4.85 E+06$ & $1.76 \mathrm{E}+09$ & $2.11 E+09$ \\
\hline $1.25 \mathrm{E}+07$ & $1.54 E+09$ & $1.65 \mathrm{E}+09$ & $1.56 \mathrm{E}+09$ & $1.22 E+09$ & $1.08 \mathrm{E}+09$ & $3.66 \mathrm{E}+08$ & $1.32 E+09$ & $1.50 E+09$ & $1.45 \mathrm{E}+09$ & $3.81 \mathrm{E}+07$ & $5.02 \mathrm{E}+07$ & $6.70 \mathrm{E}+07$ & $3.58 E+06$ & $1.25 \mathrm{E}+09$ & $1.48 \mathrm{E}+09$ \\
\hline $1.30 \mathrm{E}+07$ & $1.06 \mathrm{E}+09$ & $1.13 E+09$ & $1.07 E+09$ & $8.48 \mathrm{E}+08$ & $7.59 \mathrm{E}+08$ & $2.67 E+08$ & $9.17 E+08$ & $1.04 E+09$ & $1.01 E+09$ & $2.79 E+07$ & $3.65 E+07$ & $4.88 E+07$ & $2.61 E+06$ & $8.71 E+08$ & $1.02 \mathrm{E}+09$ \\
\hline $1.35 \mathrm{E}+07$ & $7.19 \mathrm{E}+08$ & $7.58 \mathrm{E}+08$ & $7.20 \mathrm{E}+08$ & $5.77 \mathrm{E}+08$ & $5.21 \mathrm{E}+08$ & $1.89 E+08$ & $6.25 \mathrm{E}+08$ & $7.03 E+08$ & $6.83 E+08$ & $1.99 \mathrm{E}+07$ & $2.59 \mathrm{E}+07$ & $3.45 \mathrm{E}+07$ & $1.86 E+06$ & $5.97 E+08$ & $6.91 E+08$ \\
\hline $1.40 \mathrm{E}+07$ & $4.68 \mathrm{E}+08$ & $4.90 E+08$ & $4.67 \mathrm{E}+08$ & $3.77 \mathrm{E}+08$ & $3.42 \mathrm{E}+08$ & $1.28 \mathrm{E}+08$ & $4.11 \mathrm{E}+08$ & $4.57 \mathrm{E}+08$ & 4.45E+08 & $1.35 \mathrm{E}+07$ & $1.76 \mathrm{E}+07$ & $2.33 E+07$ & $1.27 \mathrm{E}+06$ & $3.93 E+08$ & $4.49 \mathrm{E}+08$ \\
\hline $1.60 \mathrm{E}+07$ & $5.97 \mathrm{E}+08$ & $6.22 \mathrm{E}+08$ & $5.93 E+08$ & $4.81 \mathrm{E}+08$ & $4.40 \mathrm{E}+08$ & $1.68 \mathrm{E}+08$ & $5.27 \mathrm{E}+08$ & $5.80 \mathrm{E}+08$ & $5.67 \mathrm{E}+08$ & $1.79 \mathrm{E}+07$ & $2.31 \mathrm{E}+07$ & $3.06 \mathrm{E}+07$ & $1.68 E+06$ & $5.05 \mathrm{E}+08$ & $5.71 E+08$ \\
\hline $1.80 \mathrm{E}+07$ & $9.40 E+07$ & $9.76 \mathrm{E}+07$ & $9.30 \mathrm{E}+07$ & $7.59 E+07$ & $6.98 \mathrm{E}+07$ & $2.71 \mathrm{E}+07$ & $8.38 \mathrm{E}+07$ & $9.11 \mathrm{E}+07$ & $8.92 E+07$ & $2.90 \mathrm{E}+06$ & $3.75 E+06$ & $4.95 E+06$ & $2.75 E+05$ & $8.02 E+07$ & $8.96 \mathrm{E}+07$ \\
\hline $\begin{array}{l}\text { Total Flux } \\
\left(\mathrm{n} \mathrm{cm}^{-2} \mathrm{~s}^{-1}\right)\end{array}$ & $8.60 E+13$ & $8.92 E+13$ & $8.35 E+13$ & $6.65 E+13$ & $6.24 E+13$ & $2.83 E+13$ & $7.98 \mathrm{E}+13$ & $8.17 E+13$ & $8.19 \mathrm{E}+13$ & $3.07 E+12$ & $4.00 E+12$ & $5.17 \mathrm{E}+12$ & $3.08 E+11$ & $7.41 E+13$ & $8.03 E+13$ \\
\hline $\begin{array}{c}\text { Sic Damage } \\
\text { Rate } \\
\text { (dpa/s) }\end{array}$ & $3.0013 \mathrm{E}-07$ & 3.1812E-07 & $2.9216 \mathrm{E}-07$ & $1.9367 \mathrm{E}-07$ & $1.8016 \mathrm{E}-07$ & $6.4991 \mathrm{E}-08$ & $2.6205 \mathrm{E}-07$ & $2.6514 \mathrm{E}-07$ & $2.7459 \mathrm{E}-07$ & 5.6893E-09 & $7.4586 \mathrm{E}-09$ & $9.5076 \mathrm{E}-09$ & $5.4671 \mathrm{E}-10$ & $2.3782 \mathrm{E}-07$ & $2.6539 \mathrm{E}-07$ \\
\hline
\end{tabular}

The bottom line in this table shows dpa production rates in SiC for the irradiation facility of each column. The highest rates are in A-1 and A-10 


\subsubsection{Irradiation times for target fluences in ATR}

Given the dpa levels predicted to be attained by the $\mathrm{SiC}$ in the actual DB-FCM-LWR, it is possible to determine the length of time of irradiation in the ATR running at full power. For example, if a sample is placed in the A-10 location, irradiation of the sample to reach the softer-spectrum location dpa level would last 11.2 years (4090 days) at full power, while the dpa level of the harder spectrum location would require 12.64 years (4614 days).

In addition to these irradiation times, sample must be irradiated to (certain) failure. The fluence level (or irradiation time) required for this case will be computed using a combination of the methods presented in this report and of the methods within the PASTA code.

\section{Conclusion: Status of Methodology and Planning Development}

A preliminary investigation has been completed in support of planning an irradiation experiment in the ATR. The experiment is meant to help qualify the FCM fuel. In this report the goal was to help plan irradiation of DB-FCM fuel. However, preliminary steps in support of FCM fuel for application in LWRs other than in the Deep Burn mode have also been taken. The methodology and the computational tools that have been assembled and devised are state-of-the-art and are likely not easily found at one location. In particular, the modified version of the NJOY code for computing displacement kerma cross sections is unique. The full integration into the present methodology of the PASTA code for modeling failure rates in TRISO fuel must still be carried out.

\section{Appendix: Generic Steps in Irradiation Test Planning}

An experiment aimed at verifying the validity of a concept or that of a design is in its construction very similar to the design or concept it must verify. For example, a design or a concept possesses a definite set of characteristics (e.g., effectiveness, efficiency, and safety). Each of these characteristics may be subdivided into constituent components. The experiment that aims at verifying the design or concept must address each of these components, or at least factor them into the experiment's own design. This requirement implies that the experiment must be design and conducted within parameters that reflect those of the concept being verified. In particular, the normal performance and the limiting performance of the concept must be used as guidance or boundary conditions for the experiment. This note shows how an experiment for testing the design of the fuel for a LWR-DB reactor must be constructed to be technically effective and economically efficient.

\subsection{Boundary Conditions: the reactor design and its performance limits and objectives}

The design of the reactor, its performance characteristics, its operating conditions, and its safety requirement dictate much of the features in the design and impose physical boundary conditions on the components of the reactor, including its fuel. The conditions, normal and off-normal, that will be experienced by the fuel in the reactor are the direct result of the design and actual construction characteristics of the reactor. Consequently, before an engineer designs an experiment to test the performance of any constituent of the reactor, said engineer must possess the best description possible of the reactor design. The constituent under consideration may be any part of the reactor, including its fuel. If the experiment is constructed and carried out without the benefit of a proper preliminary design of the reactor and without the derivation of experimental protocols, including delineation of applicable ranges for 
the various parameters, the experiment may be wasteful as it could test for unrealistic conditions beyond any that could be expected in the real reactor, even under severe off-normal conditions. The converse could also be true, in which without proper guidance important operational conditions may be overlooked and not tested for. An imperative in designing a cost effective experiment is to identify all the reasonable limits for the operating conditions and performance conditions of the reactor and to devise a set of protocols and an experimental matrix that capture all the necessary cases. The boundary conditions for a rational conduct of this phase of the experiment design are provided by a model of the reactor. Such a model involves a coupled neutronic-thermo-mechanical code that can predict the feasibility of the concept or design, its effectiveness, its efficiency and its safety. In the foregoing, feasibility refers to the physical plausibility of the design with a design deemed feasible if it can actually be built and deployed with existing technology or by requiring technological advances that are determined to be possible within an acceptable prescribed timeframe. Effectiveness refers to the answer of the question "does the expected effect occur," or in the case of the $\mathrm{DB}$ concept does more destruction of $\mathrm{Pu}$ and MA occur than could be produced. Thus effectiveness is measure of the concept ability to fulfill in a significant manner the mission for which it is designed given the costs that are sunk into the facility without regard to efficiency. While efficiency of the design refers to the economy or cost effectiveness with which the mission is accomplished. Finally safety refers to the ability to fulfill the mission with an absence of adverse effects, including the requirement of continued integrity of the fuel and other constituents.

In summary, the steps and components of the preliminary design (which are discussed in the subsequent sections) are:

(i) Demonstration of the feasibility

(ii) Demonstration of the effectiveness

(iii) Demonstration of the efficiency of the concept

(iv) Optimization of the design(s)

(v) Demonstration of the safety of the optimized design

\subsection{Reactor physics (feasibility, effectiveness, efficiency and safety)}

A reactor physics model should be able to study various operating conditions of the reactor and to carry out depletion computations. The product of the use of a suite of neutronics/reactor physics codes should include the following:

Appropriate prepared cross sections, taking into account the unique physical features of the reactor such as multiple levels of heterogeneity, the mixed moderator effects, and the mixed actinides resonance effects (equivalent to the "high burnup" effects in ordinary LWRs)

(ii) Production of appropriate neutron spectra throughout the reactor core and at structural features

(iii) Derivation of neutron fluxes and neutron fluences at all locations of interest, including in the TRISO particles and in the fuel matrix

(iv) Derivation of detailed isotopics for the assessment of effectiveness and efficiency Derivation of reactivity coefficients for assessment of safety

The reactor physics model is used to determine if the design intended for application of the concept is satisfactory from the perspective of the criteria of feasibility, effectiveness, efficiency and safety. The design can be iterated upon until an optimal one is obtained. When such an optimal design is homed-in on, its overall characteristics are to be catalogued. Of particular interest are the local peaking in power and the local peaking in temperature, the actual neutron spectra in the various spectral zones, the local fluxes, the local isotopics, and depletion characteristics such as the volatile elements production rate in the TRISO 
particles. From these, radiation damage prediction quantifications can be obtained for the TRISO fuel layers and for the fuel matrix. Average, "nominal," values as well as extreme values can be obtained to serve as guidelines for the experiment design.

\subsection{Fuel performance modeling}

A fuel performance model, such as the one embodied in the PASTA code, computes the mechanical stresses in the various layers of the TRISO particle. It takes into account the temperature field within the particle and the accumulation and release of fission products, particularly volatile ones, within the various layers. The code then uses statistical models of mechanical failure to predict the failure rate under various operational conditions, which can range from normal nominal operating conditions to accident transient scenarios, such as a rod ejection event. The code can be repeatedly used for variations in the fuel and reactor design to assess the durability of the fuel and its consequence for safety of operation.

If the fuel performance model predicts an unacceptably high failure rate, the design can be altered by changing the morphology of the fuel (TRISO packing, matrix density, ...) or the core design characteristics. This can be carried our iteratively (taking into account effectiveness, efficiency, safety, and fuel performance constraints) until an overall design is attained that satisfies both reactor physics criteria for acceptability and fuel performance ones. The resulting optimal design and its corresponding fuel design should be the starting point for the design of the experimental tests for the fuel.

\subsection{Design of the experiment}

Once a design for the reactor, including its fuel, has been chosen, a set of experimental tests can be devised for the fuel. The steps necessary to the rational design of a test are outlined below:

(ii) Translate identified exposure levels into a universal exposure quantifier (e.g., displacement per atom)

(iii) For the experimental facility, determine the exposure location and exposure duration that would correspond to the same universal exposure quantifier.

(iv) For accelerated testing experiment carry out correction for higher damage saturation effects

(v) Repeat the above steps (i)-(iv) for each exposure level of the reactor design

The experimental matrix should include each of the exposure levels in the experimental facility that is identified in the process shown above. A more sophisticated model could also take into account irradiation temperatures and correct for annealing during irradiation, thus producing a likely simpler and smaller irradiation matrix.

The above discussion assumes that the reactor operating conditions and the experimental situations are correlated primarily through radiation damage and that the latter is primarily the result of atomic displacements. The discussion also assumes that at a given exposure level the failure rate of TRISO particles is governed primarily by thermo-mechanical effects (i.e, mechanical stresses and temperature). Both of these assumptions are plausible and correspond to the current state of thinking in radiation damage.

A stressor that may be important in TRISO particles, but is seldom accounted for in radiation damage models, is chemical attack by some fission product species (e.g., palladium). The effect of chemical species can be added to the experimental planning as another mechanism to be accounted for. The synergistic effects in causing failure originating in radiation damage, thermo-mechanical stresses, and chemical attack, can, as a first approximation for the purpose of experiment planning, be assumed to be linearly additive. 


\subsection{Experiment matrix/schedule}

The artifacts that can cause failure were discussed in the previous section. Their consideration leads to the design of an experiment that must account for multiple levels of radiation exposure (and corresponding microscopic damage accumulation and volatile element inventory), various temperature conditions (and corresponding thermo-mechanical effects), and possibly various chemical attack effects. The range spanned for each of these artifacts can be quantified using the reactor physics and the thermomechanical models. A properly devised experiment matrix should cover the entire range and in addition should include a control test that uses pristine un-irradiated sample on one end of the spectrum and excessively exposed sample (mimicking accidental over-exposed conditions).

If an accelerated experiment is planned, as is usually to be expected, then it is advisable to include at least two accelerated time scales in order to be able to isolate the effects introduced by the accelerated character of the irradiation protocol and hence to be able to correct for said acceleration effects.

\subsection{Test to failure}

The experimental matrix must also include a "Test-to-Failure" case, especially if the fuel design is so good that no failures occur under normal conditions. The conditions that lead to a failure can be identified using the PASTA code and hence the Test-to-Failure case can be devised from the inception of the experimental process.

The models can be used to predict the exposure and temperature that result in failure of a number of TRISO particles. The reason this last test is necessary is that it helps to validate the models, the test statistics and supports the determination of correctness of the postulated failure mechanisms. Overall, it is an essential tool in the final interpretation of the experimental results and in the identification of possible further design improvements if they are still desired.

\subsection{Planning for long-lead items}

The planning of an experiment must include the acquisition of samples and equipment. Some items must wait for the experiment to be fully designed before they can be acquired, as their precise specifications cannot be guessed prior to the completion of the experiment design. However, other items may be specified well in advance of the completion of the experiment design. For those of such items that require a long time to manufacture or otherwise procure, the acquisition process and/or the planning for it must start during the early stage of experiment design. Such items may include capsules, special rabbits, and even the scheduling of access to irradiation and post-irradiation testing facilities. Other items that are independent of fuel design may also be planned for early.

\subsection{Drawing conclusions from the experiment}

The ultimate evidence of success of an experimental program is its ability to produce information that either validates the concept/design under consideration or to show the limits of validity for the concept/design and point out directions for the improvement of the concept/design. The test for this success (or lack thereof) can be carried out through a comparison between the experimental and the predictive theoretical (or code) results. The minimal steps for this ultimate test are:

(i) Reporting the experimental results and findings

(ii) Comparison of experimental results with model-predicted behavior

(iii) Provide interpretation of concurrence and/or discrepancies between experimental results and model-predicted behavior and provide feedback to modeling effort

(iv) Upon resolution of discrepancies provide final interpretation of results 


\subsection{Conclusion}

This note has presented a discussion of the necessary steps for experiment design. It is shown that modeling is an integral part of the design, exploitation and interpretation of experiments in verification or validation of a concept of a design.

\section{REFERENCES}

1. R.M. Versluis, F. Venneri, D. Petti, L. Snead, D. McEachern, "Project Deep-Burn: Development of Transuranic Fuel for High-Temperature Helium-Cooled Reactors," Proc. HTR 2008, Washington D.C., USA, 28 Sept. - 1. Oct. (2008).

2. B. Boer, A. Ougouag, "Core Analysis, Design and Optimization of a Deep-Burn Pebble Bed Reactor," Proc. PHYSOR-2010, Pittsburgh, Pennsylvania, USA, 9 May - 14 May 2010.

3. Y. Kim, F. Venneri, "Optimization of One-Pass Transuranic Deep Burn in Modular Helium Reactor," Nuclear Science and Engineering 160, No. 1, p. 59, 2008.

4. D.A. Petti, D.A., J. Buongiorno, J.T. Maki, R.R. Hobbins and G.K. Miller, "Key Differences in the Fabrication, Irradiation and High Temperature Accident Testing of US and German TRISO-Coated Particle Fuel, and their Implications on Performance," Nuclear Engineering and Design, 222, Issues 2-3, pp. 281-297, December (2002).

5. AGR-1 Irradiation Experiment Test Plan, INL/EXT-05-00593, Rev. 3, INL, October 2009

6. AGR-1 Irradiation Test Final As-Run Report, INL/EXT-10-18097, INL, April 2010

7. Boer, B., A.M. Ougouag, J.L. Kloosterman and G.K. Miller, "Stress Analysis of Coated Particle Fuel in Graphite of High-Temperature Reactors," Nuclear Technology, 162, June (2008).

8. Venneri, F., et al., "High Temperature Reactor (HTR) Deep Burn Core and Fuel Analysis: Design Selection for the Prismatic Block Reactor," Idaho National Laboratory, INL/EXT-10-19973, September 29, 2010.

9. G.F. Sengler, F. Foret, G. Schlosser, R. Lisdat, and S. Stelletta, "EPR Core Design," Nuclear Engineering and Design, 187, pp. 79-119 (1999).

10. R.N. Morris and P.J. Pappano, "Estimation of Maximum Coated Particle Fuel Compact Packing Fraction," Journal of Nuclear Materials, 361, pp. 18-29 (2007).

11. R. Sonat Sen, Michael A. Pope, Abderrafi M. Ougouag and Kemal O. Pasamehmetoglu, "Assessment of Possible Cycle Lengths for FCM-fueled LWR Concepts," to be submitted for publication.

12. G. Marleau, A. Hébert, R. Roy, “A User Guide for DRAGON Version 4," IGE-294, École Polytechnique de Montréal, October, 2008.

13. A. Hébert, "A Collision Probability Analysis of the Double-Heterogeneity Problem," Nuclear Science and Engineering, 115, No. 2, p. 177, 1993. 
14. N. Hfaiedh, A. Santamarina, "Detemination of the Optimized SHEM Mesh for Neutron Transport Calculations," Proc. Mathematics and Computation, Supercomputing, Reactor Physics and Nuclear and Biological Applications, Avignon, France, 12 Sept. - 15 Sept. (2005).

15. M.T. Robinson, BNES Nuclear Fusion Conference Proceedings, UKAEA, September 1969.

16. J. Lindhard, et al., Kgl Danske Videnskab Selskab Mat-Fys Medd, 33, 10 (1963) 3.

17. A.M. Ougouag, et al., Proc GLOBAL 2003, American Nuclear Society, November 2003.

18. A.M. Ougouag, et al., Proc PHYSOR 2004, American Nuclear Society, April 2004.

19. C.A. Wemple and A.M. Ougouag, Proc BE 2004, American Nuclear Society, November 2004.

20. A.M. Ougouag and C.A. Wemple, Proc HTR 2004, IAEA, September 2004.

21. .E. MacFarlane, et. al., LA-12740-M (UC-413), Los Alamos National Laboratory, October 1994.

22. M.J. Norgett, M.T. Robinson, and I.M. Torrens, Nucl Eng Des 33 (1975) 50.

23. A.M. Ougouag, C.A. Wemple, and T.J. Dolan, in preparation. 